\title{
RULES, ADJUDICATIONS, AND OTHER SOURCES OF LAW IN AN EXECUTIVE DEPARTMENT: REFLECTIONS ON THE INTERIOR DEPARTMENT'S ADMINISTRATION OF THE MINING LAW
}

\author{
PETER L. STRAUSS*
}

Professor Strauss presents in this article a detailed case study of policymaking by the Department of the Interior in its administration of mining law. The antiquated nature of the General Mining Law of 1872, essentially unchanged since its enactment, has placed a great responsibility for "writing" the law of mining claims upon the Department, highlighting the problems that exist with the Department's internal allocation of its policymaking function.

The focus of this picce is a study of those problems and an examination of possible remedies. Professor Strauss criticizes, in particular, the inaccessibility of Department "law" and the Department's excessive reliance upon adjudication rather than rulemaking to make policy. Even though rulemaking would create a more accessible body of agency policy and procedure, increase public participation and advance other jurisprudential values, bureaucratic obstacles currently discourage resort to this vehicle. Moreover, the Department's rulemaking branch has virtually no control over the adjudicatory body, leaving essentially unfettered policymaking power in the hands of a body whose ow'n procedures make it unsuited for the task; this bifurcation of the rulemaking and adjudicatory functions within the Department has also resulted in an incoherent and inconsistent overall departmental policy.

\section{Table of Contents}

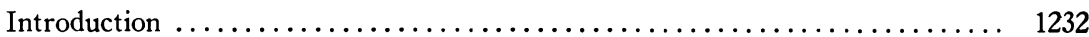

I. The Administration of the General Mining Law: Background . ....... 1234

II. The Department of the Interior's "Hidden Law" $\ldots \ldots \ldots \ldots \ldots \ldots \ldots \ldots \ldots . . \ldots 1236$

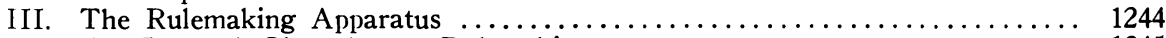

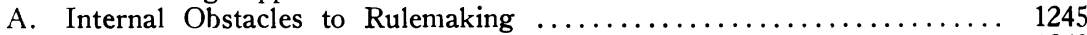

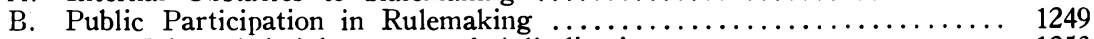

C. The Unintended Advantages of Adjudication $\ldots \ldots \ldots \ldots \ldots \ldots \ldots \ldots \ldots$

IV. A Complicating Factor: Bifurcation of the Rulemaking

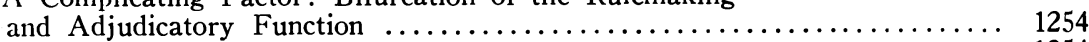

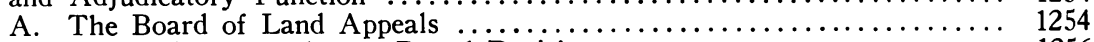

B. Secretarial Control over Board Decisions ................... 1256

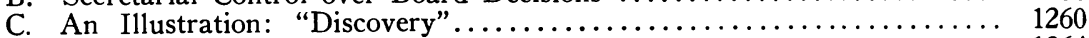

V. Rationalization of the Policymaking Function $\ldots \ldots \ldots \ldots \ldots \ldots \ldots \ldots \ldots \ldots 1264$

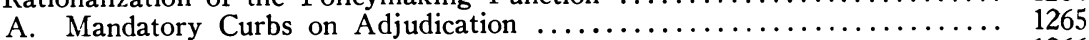

B. Reform of Internal Rulemaking Procedures $\ldots \ldots \ldots \ldots \ldots \ldots \ldots \ldots \ldots . \ldots \ldots$

C. Controls over Decisions of the Board of Land Appeals $\ldots \ldots \ldots \ldots \ldots \ldots \ldots$

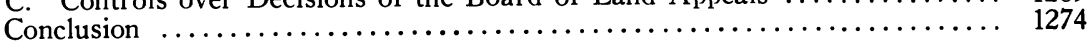

* A.B., Harvard University, 1961 ; LL.B., Yale Law School, 1964 ; Professor of Law, Columbia University School of Law. The author expresses his thanks to the Administrative Conference of the United States, to its Committee on Licenses and Authorizations, to James Potter, J.D., Columbia, '73 and William McKeown, J.D., Columbia, '74 and to his colleagues Walter Gellhorn, Arthur Murphy and Abraham Sofaer. 


\section{INTRODUCTION}

As the Surpreme Court has reminded us in the Term just concluded, it may seem more sensible for administrative agencies to formulate important policy for general application through the promulgation of rules than through the haphazard processes of litigation, but few tools exist for forcing that choice. ${ }^{1}$ The Court was appropriately skeptical of the value of rigicl requirements or judicial supervision in this sphere; while not denying the possibility that an agency's discretion to allocate policy formulation between rulemaking and adjudication could be abused, the Court was not disposed to find such abuse where Judge Friendly for the Second Circuit Court of Appeals had found it, in the much-debated providential advantages of one or the other form of agency action for creation of sound policy." If such an abuse is ever to be found, it hinted, it will only be in circumstances in which new policy sharply departs from prior practice, and the adverse consequences of imposing liability for actions undertaken in reliance on the prior rules are severe. ${ }^{3}$

Although scholarly and judicial consideration of the problem has been directed chiefly to the National Labor Relations Board and other independent federal regulatory agencies, ${ }^{4}$ the most dramatic legislative proposal for control of that choice may have emerged from the Report of the Public Land Law Review Commission. ${ }^{5}$ That bipartisan public body was commissioned by Congress to map a program of legislative action that would bring the country's public land laws out of their present chaos, and the agencies administering them into greater efficiency. ${ }^{6}$ The Commission recommended that "Congress should require public land management agencies to utilize rulemaking to the fullest extent possible in interpreting statutes and exercising delegated discretion, and should provide legislative restrictions to insure compliance with this goal." 7 The product of this recommendation was a bill introduced into the House during the Ninety-second Congress, which, among its other effects, would have prohibited public land agencies from effecting any change in

1. NLRB v. Bell Aerospace Co., Division of Textron, Inc., 94 S. Ct. 1757 (1974).

2. Compare id. at $1770-72$ zvith Bell Aerospace Co., Division of Textron, Inc. v. NLRB, 475 F.2d 485, 495-97 (1973).

3. $94 \mathrm{~S}$. Ct. at 1771-72.

4. Id.; NLRB v. Wyman-Gordon Co., 394 U.S. 759 (1969); SEC v. Chenery, 332 U.S. 194 (1947) ; NLRB v. Majestic Weaving Corp., 355 F.2d 854, 859-61 (2d Cir. 1966); Bernstein, The NLRB's Adjudication-Rule Making Dilcmma Under the Administrative Procedurc Act, 79 YALE L.J. 571 (1970); Robinson, The Making of Administrative Policy: Another Look at Rulcmaking and Adjudication and Administrative Procedurc Reform, 118 U. Pa. L. Rev. 485 (1970) ; Shapiro, The Choicc of Rulcmaking or Adjudication in the Dcvelopment of Administrative Policy, 78 Harv. L. Rev. 921 (1965) ; Peck, The Atrophicd Rulc-Making Powers of the National Labor Relations Board, 70 YALE L.J. 729 (1961).

5. Public Land Law Review Comm'n, One Third of the Nation's Land (1970) [Hereinafter cited as PLLRC REPORT].

6. 43 U.S.C. $\$ \S 1391-1400(1970)$; sce H.R. REP. No. 1008, 88th Cong., 1st Sess. (1964) ; S. ReP. No. 1444, 88th Cong., 2d Sess. (1964).

7. PLLRC REPORT, supra note 5, at 251-53. 
policy except through the medium of rulemaking, and would have forbidden application against the interests of any private person of any standard or interpretation not previously embodied in a statute or departmental regulation. ${ }^{8}$ Vigorously opposed as a prescription for administrative paralysis by Roger Cramton, then Chairman of the Administrative Conference of the United States," the bill never reached the House floor. The effort, however, suggests that a study of the allocation of policymaking between rules and adjudication in the Department of the Interior, the chief land management agency, may bear on the general debate.

The study which follows grew out of a project undertaken for the Administrative Conference during the summer of 1972. The study was principally concerned with the Department's adjudicatory procedures for determining the validity of mining claims asserted under the General Mining Law of $1872 ; 10$ those results will be published elsewhere presently. ${ }^{11}$ One quickly discovered, however, that the adjudication and the bureaucratic processing leading up to it rest on a complex and often hidden body of internal "law" interpreting the rather sparse provisions of the mining statutes. It became natural to ask how that policy was formulated and applied, where and how it could be found by the interested prospector or his lawyer, and what factors (short of the draconian measures proposed in the House of Representatives) might tend to rationalize the policymaking function and make existing policy more accessible. The question is complicated, as will appear, by the placement of public land

8. H.R. 7211, 92d Cong., 1st Sess. § 6(g) (1971).

9. Hearings on H.R. 7211 Before the Subcomm. on the Environment of the House Comm. on Insular and Interior Affairs, 92d Cong., 1st Sess., ser. 92-20, at 73-76 (1971); sce also id. at 148-49, 166-67.

10. 30 U.S.C. §§ $21-43$ (1970).

11. Strauss, Procedures of the Department of the Interior With Respect to Mining Claims on Public Lands, to be published in 1974 UtaH L. Rev. 185. Recommendations generated by the study were adopted by the Adninistrative Conference May 30, 1974. Administrative Conference of the United States, Recommendation 74-3: Procedures of The Department of The Interior with Respect to Mining Claims on Public Lands.

In addition to the fairly extensive literature generated by the importance of the matters discussed to the mining industry, by the work of the Public Land Law Review Commission, see C. McFarland's excellent Administrative Procedures and The Public LANDS (1969), and by the prospects of reform that the Commission's work has generated, the study drew on extensive, if somewhat impressionistic, interviews conducted during the summer of 1972. Four weeks in Denver, and one in Salt Lake City, permitted interviews with most of the personnel responsible for the minerals program in the Colorado and Utah State Offices and the Denver (Regional) Service Center of the Department's Bureau of Land Management, the Denver and Salt Lake City Regional Solicitor's Offices of the Department of Interior, the Department's Salt Lake City Adninistrative Law Judges, and the corresponding officials of the Department of Agriculture and its National Forest Service. It was possible to obtain unrestricted access to the files in all these places. During the same period, it was also possible to talk with a number of lawyers who had had a broad range of experience with the Department in these matters, in both private and public practice. These included a former Assistant Attorney General of the United States responsible for litigation involving the Department of the Interior, now in private practice; house counsel for a large mining firm; counsel for a conservation organization; and several counsel in private practice who frequently represent mining interests, both large and small. Conversations in Washington with members of the Solicitor's Office, the Bureau of Land Management, and the Office of Hearings and Appeals, both before and after this period, confirmed much of what had been learned. 
administration in an executive department, whose single titular head cannot supply in more than nominal capacity the coordination of policy for which he is ostensibly responsible. The following pages present these aspects of the Report to the Conference.

\section{The Administration of the General Mining Law: Background}

The General Mining Law, essentially unchanged in these respects since its enactment, permits prospectors who have found valuable minerals on public lands—or, in practice, a likely spot for their occurrence-to mark off, or locate, a limited area of the ground as a claim; the details of this ritual are left to state law. ${ }^{12}$ While he ordinarily need not state as part of his claim what minerals he believes he has found, the prospector acquires no rights against the federal government until actual discovery of a "valuable mineral." At that moment, assuming all other necessary rituals have been performed, the locator acquires an absolute right of possession against the Government to use his land for mining purposes-a right which has been strongly and uniformly described as "property in the fullest sense of that term." 13 The moment of "discovery" is thus a crucial event, and the concept of "discovery," central. Should the land be administratively withdrawn from the operation of the mining laws before that point, no valid claim attaches; and should any dispute arise as to the validity of the claim, the issue of discovery is likely to be the decisive point.

Such disputes arise chiefly in two contexts. The General Mining Law provides that a miner may acquire a patent to his claim, fee simple title, on payment of a few dollars per acre and demonstration to the Department of the Interior that he has made a discovery and has invested at least $\$ 500$ work in the development of his claim. The miner may also have to defend the validity of his location if the government initiates a contest proceeding, a proceeding usually brought only if an actual conflict exists over the use of the land (such as would be occasioned by a withdrawal) or if it proposed to deny a patent application. Patent applications are in fact comparatively rare. ${ }^{14}$ The application process has become increasingly complex, time-consuming and expensive over the years, and a miner who fails to establish the validity of

12. 30 U.S.C. $\S \S 22,26,28,35$ (1970) ; cf., e.g., 43 C.F.R. § 3831.1 (1973) (location of placer claims). The state laws are described in 1 Rocky Mountain Mineral Law Foundation, American LaW of Mining $\$ \S 5.45-5.80$ (1973) [hereinafter cited as Am. L. Mining] and in a report prepared for the Public Land Law Review Commission, 2 Twitty, Sievwright \& Mills, Nonfuel Mineral Resources of the Public Lands, 503-48 (1970) [hereinafter cited as Nonfuel Minerals].

13. See, e.g., Best v. Humboldt Placer Min. Co., 371 U.S. 334, 335 (1963); Wilbur v. United State $e x$ rel. Krushnic, 280 U.S. 306, 316 (1930) ; Black v. Elkhorn Min. Co., 163 U.S. 445, 449 (1896).

14. Between 1961 and 1970 , only 631 mineral patents, covering 81,697 acres were issued; an additional 300 mill sites, small tracts associated with mineral claims, were also patented. Hearings on H.R. 7211 Before the Subcomm. on the Environment of the House Comm. on Interior and Insular Affairs, 92d Cong., 1st Sess., ser. 92-20, at 148 (1971). 
his claim, under departmental interpretation, stands to lose the claim as well as to have his application rejected. ${ }^{15}$

Responsibility for administering the mining laws within the Department of the Interior falls chiefly on its Bureau of Land Management, a constituent part of the Department under the control of its Assistant Secretary for Public Lands. As the manager of over 465 million acres of public domain, the Bureau has numerous other responsibilities, many of them thought to be more important than mining matters. In Washington, however, a branch of the Bureau's Resources Department is responsible for coordinating minerals policy and has major responsibility for the Bureau's contribution to rulemaking in the area; the Bureau's regional offices supply further policy assistance; and each of its state offices includes a number of mineral examiners and a Land Law Examiner responsible for the technical aspects of initiating contests, effecting proposals to withdraw otherwise open lands from application of the Mining Law, and processing patent applications.

The Solicitor of the Department of the Interior is also a significant figure. The Solicitor's office comments on any proposed rulemaking, publishes occasional interpretive rulings, and presents the Department's case in adjudicatory proceedings involving the validity of mining claims once they have reached the stage of active litigation. Moreover, the Solicitor exercises substantial influence over the rulemaking process by coordinating and supervising efforts within the Department.

The third constituent of the Department participating in policymaking, although chiefly as an incident to adjudication, is its Office of Hearings and Appeals. An administrative law judge associated with that office will hear the litigation in the first instance, and the result may be appealed to the same office's Board of Land Appeals, whose seven members sit in Virginia, isolated from the Department's center in Washington, D.C. Except for a still-theoretical possibility of secretarial intervention, the Board's decision is final and binding on the Government; judicial review is available at the behest only of a disappointed private litigant. Ordinarily, the Board plays little role in the formulation of substantive policy through rule or other general policy statement.

While the General Mining Law confers on the Department far less apparent discretion than do most statutes which it administers, the antiquity of the law has combined with the changing character of the Department's mandate to produce considerable strain. When the statute was first enacted, disposal of the public domain was the governing policy; a plenitude of statutes then identified the appropriate uses of the public domain and provided for its allocation to private citizens who could give some indication that they would put it to those uses-in the case of mineral lands, by discovery of a mineral

15. United States v. Carlile, 67 I.D. 417, 423-27 (1960) ; Terry \& Stocker, 10 I.B.L.A. 158 (1973); see Barton v. Morton, 498 F.2d 288, 292 n.8 (9th Cir. 1974). 
deposit and the performance of limited development work. Since that time, increasing awareness of the finite nature of the nation's public land resources has led to a regime of public retention and development of the remaining lands ; sale of these lands or provision for limiting access to their use is now exceptional. This changing view of public land resources policy, however, is in conflict with the provisions of the General Mining Law, which permit possessory rights over public lands to be acquired in relative secrecy and make no provision for use regulation, fair compensation for value, or early demonstration by the claimant of the merit and good faith of his claim.

These further elements are inconsistent with a policy of public retention and development of the public domain, whether or not one believes, as mining industry spokesmen do, that free exploration of public lands and acquisition of possessory rights upon discovery are the most effective stimulants for mineral development. And this inconsistency, undoubtedly, has led the Department into a grudging and somewhat tight-fisted approach towards claims made under the mining laws. In an effort to prevent unwarranted dispositions and misuse, standards are applied with increasing rigor and traumatic consequences are visited upon failure to meet them. Yet while miners complain that the Department is thus "making policy" rather than "applying the law," the Department cannot tenably be required to ignore the striking changes in its general mandate, even if this particular statute has been more durable than most. In the years since the statute was passed, the Department, like all other administrative bodies, has had to make policy to conform the statute as closely as possible to its other tasks and general charge. The appropriate questions are how, and how well, the Department has done that work. This assessment cannot be made simply from the perspective of efficiency, either in processing claims or retaining public lands in government hands; fairness to clainants and the adequacy of departmental procedures in honoring claimants' reasonable expectations and in furthering the residual congressional purpose expressed in the statute must also be considered.

\section{The Department of the Interior's "Hidden Law"}

While the General Mining Law itself has not been significantly amended since 1872 , intervening crises have led Congress to surround it with a variety of exceptions and special rules and procedures. Claims must occasionally be registered with the government, but usually not ${ }^{16}$ rights acquired under a claim vary from statute to statute in minute, unpredictable and often inexplicable ways. ${ }^{17}$ This confusion cries for rationalization by statute, hopefully

16. Registration is required for withdrawals on power sites, 30 U.S.C. $\$ \S 621-625$ (1970), coal lands, id. $\S \S 541-541 \mathrm{i}(1970)$, and certain revested forest lands in Oregon, 43 U.S.C. § 1181 (1970).

17. For example, claims under the coal lands statute are limited in duration, 30 U.S.C. $\S 541 \mathrm{i}$ (1970), but claims under the other two statutes are not limited; two of the statutes 
forthcoming. In the meantime, it has produced a babel of regulations mirroring and often expanding upon the statutory inconsistencies and confusion, ${ }^{\mathbf{1 8}}$ and creating an urgent need for information about the functioning and policies of the Department and the Bureau.

The "small man" character of many prospectors and the high level of suspicion and distrust with which they appear to regard the Bureau make openness about policy particularly important. By and large, the Bureau is not an agency that deals with large corporate interests able to acquire sophisticated legal services for their dealings with government. Small miners and their lawyers can little afford searching hither and yon for traces of the Bureau's operating law; the need to do so contributes significantly to their view that the agency is arbitary and undeserving of their cooperation. ${ }^{19}$ For the small miner, any confrontation with the local representative of "big government" involves a decided imbalance of resources. The Bureau has responded to the demands of such a setting well in other contexts $;^{20}$ clarity and concision are equally called for here.

Despite the apparent utility of rules in such circumstances, the Department's use of its rulemaking powers is viewed by nearly all as insufficient. ${ }^{21}$

have been construed to require that the notice tie the claim to the public land survey, 43 C.F.R. §§ 3721.1(d) (coal lands), 3821.2 (revested lands) (1973), while the third, like the General Mining Law, has not.

18. C. MCFARLAND, supra note 11 , at 238,242.

19. Their attitude appears to this observer to represent more folklore than fact, for local administrators seem thoughtful and concerned. Yet few conversations outside governmental circles were unmarked by distrust of agency motives.

20. For example, the Federal Range Code successfully consolidates in regulatory form nost Bureau policies dealing with grazing rights. 43 C.F.R. §§ 4110-4714 (1973).

21. See, e.g., PLLRC REPORT, supra note 5, at 251-52; C. McFarland, supra note 11, at 232-61, 306-10; McCarty, $A$ View of the Decision-Making Process Within the Department of Interior, 19 A.B.A. Admin. L. Rev. 147, 168-72; Carver \& Landstrom, Rulemaking as a Means of Exercising Discretion in Public Actions, 8 ArIz. L. Rev. 46 (1966). No such problem seems to have been uncovered by the Attorney General's Committee on Administrative Procedure in 1941, Administrative Procedure in Government Agencies, S. Doc. No. 10, 77th Cong., 1st Sess., pt. 7 at 55 (1941) (Department of the Interior); see Bloomenthal, Administrative Procedures, in Symposium on the Public Land Law Review Commission Report, 6 Land \& W.L. Rev. 1, 241 (1970).

The expectation that public land agencies would adopt their major policies by widely published rules is not a new one; it was expressed at the nation's birth, when land was our principal asset. Professor McFarland quotes the following passage submitted to the House of Representatives in 1790, by the then Secretary of the Treasury, Alexander Hamilton, in conjunction with his Plan for Disposing of the Public Lands:

That the Commissioners of the General Land Office shall, as soon as may be, from time to time, cause all the rules and regulations, which they may establish, to be published in one gazette, at least, in each State, and in each of the Western Governments where there is a gazette, for the information of the citizens of the United States. Regulations like these will define and fix the most essential particulars which can regard the disposal of the Western lands, and where they leave any thing to discretion will indicate the general principles or policy intended by the Legislature to be observed: for a conformity to which the Commissioners will, of course, be responsible. They will, at the same time, leave room for accommodating to circumstances, which cannot, beforehand, be accurately appreciated, and for varying the course of proceeding, as experience shall suggest to be proper, and will avoid the danger of those obstructions and embarrassments in the execution, which would be to be apprehended from an endeavor at greater precision and more exact detail. 
"[T] he making of regulations by and large has been the instrument of routine administration rather than one for the formulation of policy." ${ }^{22}$ Policy is formulated through Manual directives, temporary directives, Solicitor's opinions, or-particularly in the case of the mining laws-through case adjudication under the pressure of day-to-day emergencies.

Adjudication has seemed less satisfactory than rulemaking as a vehicle for policy formulation. It is inherently easier for either Congress to exercise oversight responsibilities or private individuals to acquire information about policy from a collection of current regulations than from a series of adjudications, often changing in tone and direction with changes in administration or in administrative imperatives. The problems of divining law from case decisions are compounded when some of the decisions that may be relied upon are available in one place, some in another, and others hardly at all. When the possibility arises that important shifts of policy will occur in litigation, few of those affected will be notified, and the quality of representation afforded private interests in the case cannot be assured. ${ }^{23}$

On the most basic level, as Professor McFarland points out, ${ }^{24}$ the Department has failed to make clear to the public its own internal structure. The Department takes literally the requirement of section 3 of the Administrative Procedure Act ${ }^{25}$ that it publish "in the Federal Register" its organizational structure, including organizational descriptions and a guide to the public indicating how it may get information or decisions or make submittals or requests. Such notices are published in the Register but are not consolidated in the Code of Federal Regulations or elsewhere. ${ }^{26}$ The entry for the Bureau of Land Management in the Government Organization Manual is brief and unhelpful ; Parts 1000 to 1719 of the Department's regulations, reserved to set out "General Management" regulations governing the Bureaul, stand vacant. Parsing the Bureau's structure through the Federal Register is a complex and unrewarding task. Perhaps the fault lies in part, as Professor McFarland suggests, in the wording of section 3. ${ }^{27}$ Publication "in the Federal Register,"

28 Am. State Papers (Public Lands, I) 8-9 (1832), quoted in C. McFarland, supra note 11 , at 232 . The Department (and its predecessors) have in fact used rules widely since that time.

22. C. MCFARLAND, supra note 11 at 242 .

23. A striking example is cited in McCarty, supra note 21, at 171 11.129: In Hugh S. Ritter (Thomas M. Bunn) 72 I.D. 111 (1965), remanded Civ. Act. No. 2615-65 (D.D.C., June 28, 1966), the Secretary announced a policy of refusing further classifications for agricultural use of extensive, potentially irrigable lands in California, in a case involving only 40 acres of land and two appellants-indeed, in this case, without the benefit of briefing on the issue by either party. Even if the Department gave proper notice to the litigants that this issue would be considered, it is at best uncertain that interests in the total acreage affected by the decision would be well represented by the legal services applicants for 40 acres could afford.

24. C. MCFARLAND, supra note 11 , at 264-71.

25. 5 U.S.C. \& 552 (1970).

26. For a holding that this suffices, see United States v. Tijerina, 407 F.2d 349, 354 n.12 (10th Cir. 1969).

27. C. MCFARLAND, supra note 11 , at 266-67. 
without periodic consolidation in the Code of Federal Regulations or some similar publication, provides inherently insufficient notice for any matter intended to have long-term effect.

The spirit of section 3 , whether or not fully mirrored in its words, requires a greater effort to make organizational information available in convenient form. To its credit, the Bureau distributes through its state offices a series of leaflet handouts, each abstracting the regulations applicable to mineral locations under a particular statute. But the unalloyed regulations are hardly enough. A lawyer representing an occasional prospector or the prospector himself requires some guidance to determine which of the several leaflets might apply. The civil servant seated behind the office's information desk, friendly and helpful as that officer may be, is unlikely to possess the required knowledge. All the attorneys interviewed shared the experience of finding through perseverance a knowledgeable bureaucrat who was willing to spend the time to share his information with them. Each of them, however, seemed to think this his particular bit of luck. The public should not have to depend on the fortuity of finding the right official by word of mouth-even in a relatively small office of an agency with a proud tradition of helpful public service. Regular publication of a full description of the Bureau's central and field organization, showing relevant lines of authority, would eliminate the premium now placed on personal knowledge or on perseverance in tracking editions of the Register.

This criticism applies a fortiori to the Bureau's operating procedures for dealing with mining matters. Here, as Professor McFarland notes, the regulations afford no realistic description of how the Bureau reaches initial decisions regarding mineral claims, or where information and advice on these matters can be obtained. The clainant

is left to wend his way through the administrative jungle by such word of mouth instructions as he may obtain from officials of all degrees-which he may follow or not at his peril."28

For example, responding to miner fears of Bureau arbitrariness in bringing actions to contest the validity of mining clains, the Bureau has adopted a variety of self-imposed limitations: contests will be brought only in cases of demonstrable need-where a patent application appears insufficient, where an application for a competing use is in hand, where a withdrawal has been made, or, more recently, where there is flagrant abuse or trespass: multiple proceedings against the same lands will be avoided. These policies have been announced in speeches or by other informal means, with copies circulated in memorandum form within the Bureau, but have not been formally published.

Helpful policy information is frequently absent from the Department's regulations. ${ }^{29}$ The Department treats an enormous body of general statement

28. Id. at $159-60$.

29. For example, the concept of "discovery" is central to the validity of mining 
about policy and procedure-including matters it treats as binding in administrative litigation-as suitable for staff manuals and instructions rather than rulemaking. For example, the Manual provisions regarding applications for patents contain several requirements, unmentioned in the regulations, which must be met before a patent can issue. In the Colorado office, applications have been sent back for correction on these grounds, to the understandable consternation of the lawyers involved. ${ }^{30}$ Unlike the regulations, the Manual provisions also reflect detailed interpretations of concepts central to claims validity or patent issuance-the meaning assigned to "discovery," or the definition of the necessary "contiguity" of two clains covered by a single application. ${ }^{31}$ Again. both the Bureau Manual and the Forest Service Manual contain the "treaty" between the two organizations, allocating responsibility between them for the various aspects of processing mining claims on Forest Service Lands: this otherwise unpublished document figured importantly in a recent administrative appeal, providing the reason why a policy governing conduct within the Bureau would not apply. ${ }^{32}$ Materials such as these need never be published in the Federal Register, ${ }^{33}$ with or without an opportunity for comment after proposal, and never appear in the Code. Under section 3(b) of the Administrative Procedure Act, it suffices that the Bureau makes available manuals and instructions for public inspection and copying, although they may also be published and offered for sale. ${ }^{34}$

To say that the manuals are available for inspection, moreover, is somewhat misleading. While the relevant staff is helpful and aware of the obligation to produce the manuals, ${ }^{35}$ the manuals are unwieldy and, in part, outdated. The Bureau Manual, for example, is divided into two editions, old and new, each rather poorly indexed and comprising several looseleaf volumes. Entries bearing directly on the General Mining Law have not yet been revised, and so remain in the "old" Manual; but some other relevant provisions, such as policy objectives in mineral development, instructions on mineral reports and policies concerning classification and withdrawal, are in the "new" Manual. And what is in either edition may be affected by supplemental "temporary"

claims. Despite a 100-year history of elaboration of its meaning by the Department, no attempt at definition appears in the regulations.

30. E.g., VI Bureau of Land Management, U.S. Dep't of the Interior, Manuai. $\S 3.1 .8 \mathrm{~F}$ (1958) [hereinafter cited as BLM, MANUAL]. The same criticism may be applied to the corresponding sections of the Forest Service Manual. Sce gencrally PLLRC REPORT, supra note 5 , at 252 .

31. E.g., VI BLM, Manual § 5.2.12C; id. § 3.1.15B(3). While these interpretations are in the form of instructions to claims examiners, they do not constitute the sort of instructions regarding permissible departures from an announced norm or negotiation stance that could prove embarrassing if widely disseminated.

32. Ed Bergdal, 74 I.D. 245 (1967).

33. In fact, the Bureau and the Department have each published a few Manual provisions concerned with environmental matters in the Federal Register, 36 Fed. Reg. 19343 (1971) ; 37 Fed. Reg. 15015 (1972), but neither follows a consistent practice of publishing entries of public significance.

34. 5 U.S.C. \& 552 (a) (2) (1970).

35. 43 C.F.R. \& $2.5(\mathrm{e})(1973)$. 
instructions, which may or may not have been filed with the Manual provisions affected and which may or may not still be operative. ${ }^{36}$ Or, as now seems to be the case with respect to the instructions concerning mining claims, there may be an office understanding that the stated procedures, unrevised in almost two decades, will no longer be followed.

Mere availability of the Manual for inspection and copying fails to satisfy the Department's publication responsibilities for at least two other reasons. Since the Manual is not included in the departmental indexes, the Department may not rely on it to any outsider's detriment, absent actual notice. ${ }^{37}$ Further, the failure to differentiate materials more properly contained in regulations from staff instructions and other less general matter appropriate to the Manual ${ }^{38}$ creates the appearance that the Manual constitutes part of the agency's governing law, and thus undermines the argument that the Manual as a whole lacks authority to bind the Bureau or the Department ${ }^{39}$-an argument unanimously maintained by departmental attorneys and Bureau officials. Their reluctance arises in part from apprehensions about the Manual's

36. These "temporary" directives are particularly obscure, yet may affect quite significant matters, such as Bureau interpretations of the Department's published rules. Their preparation is as thorough as Manual directives, yet their inevitable effect is to postpone, often indefinitely, the issuance of corresponding manual instructions. No reason appears why the Bureau could not imitate the Geological Survey and issue these directives in the form of Manual additions. Reliance on temporary directives in dealing with mining law matters, to the exclusion of Manual revision, promotes "hidden law."

37. A final order, opinion, statement of policy, interpretation, or staff manual or instruction that affects a member of the public may be relied on, used, or cited as precedent by an agency against a party other than an agency only if-

(i) it has been indexed and either made available or published as provided by this paragraph; or

(ii) the party has actual and timely notice of the terms thereof.

5 U.S.C. \& 552(a) (2) (1970). The indexing requirement could be a useful safeguard against "hidden law," particularly if, as seems to have been expected, only matters of significance are included in the indexes. S. REP. No. 813, 89th Cong., 1st Sess. 7 (1965) ; H.R. Rep. No. 1497, 89th Cong., 2d Sess. 8 (1966). Professor Davis suggests that indexes should contain every matter required by section 3 to be made available for inspection and copying, however insignificant. K. Davis, Administrative Law Treatise 141 (Supp. 1970). His unnecessary interpretation tends to disserve the requirements' broad purpose. Such catholicity is not required for protection of the citizen from secret law, encouragement of agencies to organize their law in an accessible and rational fashion, or assurance to the citizen of a reasonable opportunity to conform his behavior to applicable norms, as long as only indexed law is applied. A comprehensive index would include far more than required to show the working law of the agency and indeed, would tend to submerge it. As a practical matter, too, such an index could be maintained only at a central location, defeating in this way also its informative purpose. From the litigant's, if not the scholar's, perspective, the agency's law is once again inaccessible if such a central index may serve as authority for adverse use of any matter listed on it. See note 48 infra.

38. Inquiry produced few indications that this differentiation is made on the basis of rational principle. While new statutes or revisions of present regulations are dealt with by regulation, what has traditionally been dealt with in the Manual continues to be so, without examination as to whether developing importance might warrant a shift to the regulations.

39. Since the possible binding effect of the Manual does not constitute reliance "against a party other than an agency," it is not formally foreclosed by section 3(a) (2) of the Administrative Procedure Act. A court could give the Manual binding effect in favor of private parties, on finding that it is part of the Department's governing law. See National Forest Preservation Group v. Butz, 343 F. Supp. 696 (D. Mont. 1972), 2 ENviron L. ReP. 20571-73; Cuneo v. Laird, 338 F. Supp. 504 (D.D.C. 1972). 
accuracy and the comparatively informal manner in which it is produced, ${ }^{\mathbf{4 0}}$ perhaps more from a fear that red tape would thus be made enforceable. ${ }^{41}$ But if the Manual contains matters of general importance, ignored in the regulations, it is hard to believe that such enforcenent can be avoided. ${ }^{42}$

The 1966 revisions of section 3 of the Administrative Procedure Act ${ }^{43}$ again may be partially responsible for the Department's reliance on Manual instructions to do the work of regulations. Previously, the section provided only that "A person may not in any manner . . . be adversely affected by a matter required to be published in the Federal Register [that is, rules, policy and interpretations of general applicability] and not so published." The 1966 revisions added a directive that "staff manuals and instructions to staff that affect a member of the public" must be made available but need not be published. The effect was to soften the protection afforded by the publication requirement, by appearing to endorse the concept that some statements of policy and interpretations affecting the public need not appear in the Federal Register, or perhaps more importantly, in the Code of Federal Regulations. The provision's history gives no indication that Congress considered any such effect. It would, of course, be undesirable to deluge the Code with the undifferentiated mass that appears in the Manuals, or to stifle efforts at experimentation with informal guidelines by requiring immediate formal consolidation of all Manual provisions into the Code. Still, the public must be assured ready access to matters which affect it. The Department should vigorously review its regulations to assure that all basic procedures and substantive rules appear in the Department's regulations, and it should discipline itself to rely in its dealings with the public only on those rules or policy statements-to the exclusion of Manual entries and other unpublished policy statements.

The other important, perhaps principal, sources of departmental law are the opinions expressed in departmental adjudication concerning mining claims and, less prominently, the formal opinions of its Solicitor. The Department has been publishing major precedents and Solicitor's opinions, with comprehensive volume indexes, since enactment of the Mining Law. From 1965 on, it has also indexed its "important" unpublished decisions ; these indices can be easily obtained. ${ }^{44}$ Even so, the Department's case law is obscure in important respects. The bulk of its decisions are not printed for general distribution, but circulated

40. See text accompanying note 62 infra.

41. A manual's function as a cohesive force within a bureaucracy, cf. H. KaUfman, The ForEst RANGER (1960), is its central rationale; but that function is distinguishable from-indeed, possibly threatened by-the prospect of external enforcement.

42. National Forest Preservation Group v. Butz, 343 F. Supp. 696 (D. Mont. 1972), 2 Environ L. ReP. 20571-73; cf. James C. Goodwin, 9 I.B.L.A. 139, 155 (Geological Survey Manual definition of "workability" under Mineral Leasing Act); Stokes v. Brennan, 476 F.2d 699 (5th Cir. 1973).

43. 5 U.S.C. $\$ 552$ (a) (2) (1970), amending 5 U.S.C. $\$ 552$ (a) (2) (1964).

44. See 43 C.F.R. \& 2.4(a) (3) (1973); Parriott, The Administrative Procedure Act and the Department of the Interior, 4 Rocky MT. Min. L. Inst. 431, $436-39$ (1958). 
to a limited audience in looseleaf form. Counsel in private practice repeatedly complain that the Department draws no distinction between printed and unprinted decisions in its adjudication. Section 3(b) of the Administrative Procedure Act, as revised in 1966, clearly permits reliance on unpublished decisions, as long as they have been indexed and made available for inspection and copying. ${ }^{45}$ That should not, however, obscure the handicap borne by the private practitioner, who finds even those unprinted decisions which have been indexed essentially unavailable. Cases decided before 1955, when the Department began publication of its indexes, are yet more obscure.

Agencies such as the Department, which do print some final opinions, hardly need rely on unprinted opinions dealing with the same range of issues. Abandoning that practice would be particularly easy and appropriate for umprinted decisions predating the index. The policy judgments there are no longer fresh, and reliance on them is no more wise or necessary than it is fair. Even as to indexed but unprinted opinions, however, reliance can and should be avoided. While lawyers predictably use prior opinions to influence or justify the outcome of subsequent cases, administrative use of precedent is frequently an illusion in any event; it is surely so for the Department's unprinted opinions. The decision to print or not is premised on an assessment of the policy importance of the decision in question. Several federal courts of appeal which have recently provided for unpublished decisions have adopted rules forbidding their citation as precedent, apparently reflecting apprehensions that they are less available and the desire to point out the relative unimportance of these decisions. ${ }^{46}$ The Internal Revenue Service follows the same practice. ${ }^{47}$ The propriety of a similar rule here is forcefully apparent. ${ }^{48}$

45. 5 U.S.C. § 552(a) (2) (1970) ; Foster v. Jensen, 296 F. Supp. 1348, 1351 (D. Cal. 1966). The indexing requirement applies only to decisions reached after July 4, 1967.

46. D.C. Cir. R. 8(b) ; 10Th Cir. R. 17(c) ; cf. 5TH Cir. R. 21 ; 8Th Cir. R. 14.

47. K. Davis, supra note 37 , at 130 n. 34 .

48. Professor Davis seems to argue both sides of the issue. For determining which rules, policies and interpretations must be published in the Federal Register under section 3 (a), and which may be merely indexed and held available for public inspection, he finds the "natural line of distinction," in the face of completely unhelpful legislative history, to be whether or not the matter will be relied upon by the agency as precedent. With respect to adjudicatory opinions, however, he doubts that agencies should be permitted to resolve such issues by their publication decisions: "A private party who wants to know the agency's law should be entitled to make his own determination of what precedents have value." Id. at 140 .

Perhaps two separable issues stand confused here. Section 3 unquestionably permits any interested citizen to find out what the agency's unpublished decisions have been, so that he may let it be known that its law is not what it says it is, if that is the fact. Cf. Hanover Bank v. Commissioner, 369 U.S. 672, 686 (1962). Absent a showing verging on arbitrariness, however, it does not follow that the agency will be any more bound by its unpublished opinions than a private party. Indeed, one could not tenably hold the agency to its unpublished decisions without permitting it to rely upon them, as well, when they were to its advantage. And by that incursion, the battle to keep the task of finding the agency's law within manageable limits is lost. Whatever may be the case in larger agencies dealing with financially more momentous issues, few miners could afford the legal resources necessary to plumb the unpublished as well as the published law of the Department of Interior; the Department's attorneys, naturally, have a rather detailed professional acquaintance with unpublished matters. Attractive as it sounds, then, it would 


\section{The Rulemaking Apparatus}

The General Mining Law is perhaps atypical of the statutes the Department administers in that, except as the interstices of its rather broad formulation must be filled by interpretation, it confers little administrative discretion upon the Secretary. Thus, the function of controlling administrative discretion, as that is primarily understood, is relatively unimportant as a reason for additional rulemaking. ${ }^{49}$ But the Department enjoys considerable discretion in filling the gaps in the General Mining Law and adapting its provisions to the modern context; rulemaking may be a useful device for performing these functions. How these gaps are to be filled-by rules, manuals, temporary directives, speeches, press releases, Solicitor's opinions, or unpublished and published adjudications - is also a matter of discretion, although not consciously exercised at the agency's head; and the principal focus of critical comment has been the shaping or limiting of this discretion. ${ }^{\mathbf{5 0}}$

The Department is not handicapped in its allocation among these varying modes of policy formulation by any want of authority to make rules. Authority to establish its own procedures and to adopt interpretations of the governing statutes would be implied where not expressly conferred ;1 the Secretary's interpretations, while subject to judicial review for conformity with the statute interpreted, inevitably and properly receive broad deference, ${ }^{52}$ whether he adopts these interpretations after rulemaking or adjudication. In early days, the Department's Solicitor served both as the final departmental adjudicator and, through the medium of Solicitor's opinions, as the publisher of interpretive rulings. Although expressed as a reasoned answer to inquiry rather than in rule form, these rulings were in effect interpretive rules, and were treated as such within the Department. ${ }^{53}$

rarely be advantageous to private parties to be able to make their own determination what precedents have value. The frequently marginal character of legal services rendered private claimants in mining contests, see text accompanying notes 18-20 supra, suggests that the fundamental need is for fewer and clearer guidelines-for simplicity rather than a complex and interwoven system of law-sources. $C f$. 2 Administrative Conference of the United States, Recommendations and Reports ACUS Rec. 71-73, at 24, 175 (1973) ; id. ACUS Rec. 71-75, at 33-34.

49. Compare United States v. Kosanke Sand Corp., 12 I.B.L.A. 282, 3 Environ. L. Rep. 30017 (1973), zeith McFarland, The Unique Role of Discretion in Public Land Laz', 16 Rocky Mt. Min. L. Inst. 35 (1971); K. Davis, Discretionary Justice (1969).

50. See, e.g., C. MCFARLAND, supra note 11, at 237; McCarty, supra note 21, at 168 ; Carver \& Landstrom, supra note 21 ; PLLRC REPORT, supra note 13, at 251-52.

51. Best v. Humbolt Placer Min. Co., 371 U.S. 334 (1962); Skidmore v. Swift \& Co., 323 U.S. 134 (1944).

52. United States v. Coleman, 390 U.S. 599 (1968) ; compare Ness v. Fisher, 223 U.S. 683, 691 (1912) and Riverside Oil Co. v. Hitchcock, 190 U.S. 316 (1903) (Secretary's interpretation within possible meaning of statute and hence adopted), with United States v. George, 228 U.S. 14 (1913) and United States v. United Verde Copper Co., 196 U.S. 207 (1905) (regulation conflicts with statute and hence impermissible); $c f$. Udall v. Tallman, 380 U.S. 1 (1965).

53. E.g., Rights of Mining Claimants to Access over Public Lands to Their Claims, 66 I.D. 361 (1959). While the practice of giving opinions on such matters within the Department of course remains, public notice of these opinions has become quite rare; even 
Authority to adopt "legislative" rules, having substantive effect independent of their possible use to guide agency adjudications, does require statutory grant, but that is clearly given by the umbrella rulemaking provision of the public lands title of the United States Code. ${ }^{54}$ This power has occasionally been exercised in connection with the General Mining Law. ${ }^{55}$ Most often, however, the rules have done little more than restate the statutes-important enough for its function of consolidating relevant law in a form miners and their lawyers may find easier to deal with, but hardly sufficient. ${ }^{56}$

\section{A. Internal Obstacles to Rulemaking}

The failure to use rulemaking is far less a product of conscious departmental choice than a result of impediments to the making of rules created by the Department's internal procedures. The channels which lead to rulemaking, and to a lesser extent other forms of legislative policy statement such as production of the Manual, are so clogged with obstacles, and the flow through them so sluggish, that staff members hesitate to use them. Several years may

when the opinions are published, they may no longer be considered binding in departmental adjudication.

54. The Secretary of the Interior, or such officer as he may designate, is authorized

to enforce and carry into execution, by appropriate regulations, every part of the

provisions of this title not otherwise specially provided for.

43 U.S.C. § 1201 (1970). The "this title" referred to is not Title 43, which has never been codified, but Title XXXII of the Revised Statutes, which includes the General Mining Law. Historical Note, 43 U.S.C. § 1201 (1970); 30 U.S.C. § 21 (1970).

55. Most recently, the Department has adopted a rule requiring "substantial compliance" with the statutory requirement of periodic work to maintain the validity of a claim against the United States. 43 C.F.R. § 3851.3 (1973) ; 37 Fed. Reg. 17836 (1972). The rule draws upon the recent Supreme Court decision in Hickel v. Oil Shale Corp., 400 U.S. 48 (1970), for its standard of substantial compliance. As it appears in the statute, 30 U.S.C. $\$ 28(1970)$, the requirement is absolute, but previous interpretation had made it appear that failure to comply affected validity only as against competing prospectors. Even in adopting this rule, the Department reflected its apparent preference for policy development by other means. Left open were important questions: what degree of compliance would be considered substantial; whether past as well as future lapses in assessment work would now be taken into account in determining validity; what would be the effect of wholehearted resumption of work after a period of lapse but before any move toward cancellation had been made; and a variety of procedural issues. These questions-not matters of mere detail or oversight but, one suspects, reflective of inability to sustain agreenent or impatience with matters habitually left to resolution in other settings-are now the subject of Bureau proceedings looking towards issuance of a "temporary directive" (the most "hidden" form of legislative law in the Department) and will eventually have to be confronted through administrative litigation. Neither line of development-“temporary directive" or litigation-is under direct departmental policy control; either could produce results prejudicial to the regulation when its validity is ultimately tested in court.

56. C. MCFARLAND, supra note 11, at 13-15, 237-40. Professor McFarland draws a contrast between the paucity of mineral location regulations and the "substantial and significant" body of regulations under the Mineral Leasing Act and the Taylor Grazing Act. $I d$. at 238. It is not quite enough, as he recognizes, to note that large public and industrial interests are involved in grazing and in oil and gas; the same may be said of the domestic mining industry. The statutes governing the first two sets of interests, however, are clearly regulatory in tone, and the industries involved perhaps more accustomed to a continuing relationship with government. The General Mining Law envisions, at best, occasional contact between citizen and government, and industry spokesmen and individual prospectors seem to share a taste for rugged individualism and laissez faire government that may have infected the bureaucracy as well. Regulations suggest planning, and that remains anathema to mining interests. 
elapse between the initial movement towards a rule and its final promulgation. And like an adult game of "Telephone," Department personnel complain, what is suggested at the outset for possible rulemaking is often unrecognizable when and if a formal proposal ultimately emerges. Absent commitment at the highest levels, the process is one that is easily blocked at almost any stage by determined opposition. As a result, rulemaking may be consciously avoided by an individual with an iclea for policy change when other means for achieving the same policy ends appear to be available.

Professor McFarland, after describing at some length the procedures for rulemaking, set out in the Bureau manual, ${ }^{57}$ remarks:

[T] his "manualized" statement should be enough to deter anyone other than a most determined administrator, or one faced with some crisis such as new legislation, from attempting to propose regulations or amendments. ${ }^{58}$

57. [I]n 1967 there issued from the BLM Directives Office a manual section on Regulation Proposals explained as setting forth directions for policy as well as procedure. This exasperating document traverses its limited ground four times. It first lists the routing of staff proposals-to the Division of Management Analysis (for record keeping and transmittals), the Office of Legislation and Cooperative Relations ("for possible interest of outside groups"), the Office of Information (for "press release if necessary") - and warns against discussion "with members of the public" until cleared through "normal supervisory channels for review," cleared by the "Washington Office," and presented "if necessary" to advisory boards and other interested parties. Next, in authorizing, "any Bureau Office" to propose regulations or amendments, it commands careful drafting ("remember that they must be understandable to members of the public, as well as to specialists in the subject field"), suggests reference to departmental solicitors for legal advice if necessary, save in the case of minor, or obvious proposals; recuires "in some cases" that the "transmittal memo" contain an explanation which "is optional and depends on the extent and nature of the proposed changes," states that the Washington Office "may return draft proposals to the State Offices, for presentation to Advisory Boards and other interested parties, if desirable or required" which groups "are encouraged to send written comments to State Offices" and directs that "state Offices forward written comments to Washington with recommendations." Then, under the heading, Proposed Rule Making, it states that "subject matter specialists in the field and in the Washington Office evaluate the content of proposed regulations" and "on the basis of all comments from interested parties, appropriate staff and the Washington Office prepare rule making for approval by the Assistant Secretary, Public Land Management, or by the Secretary, and for publication"- to which is appended a 20-step procedure from "originator" to the file room for the finished product including "a substantive evaluation of proposed regulations affecting organization, management and procedure." Finally, under the heading, Final Rule Making, it states that "regulations may be prepared in final rule making form, without going through the usual proposed rule making process, if they ... impose no additional requirements on the public" and "do not affect rights of the public adversely"- which would be true of most Interior Regulations since that Department makes few significant affirmative regulations in the public land field-except that even such regulations "must be cleared through the Washington Office" in accordance with the 20 -step routine mentioned above.

C. MCFARLAND, supra note 11, at 242-43 (citations omitted).

58. Id. at 243-44. Note that all of the procedures thus described are intcrnal procedures, undertaken before publication of proposed rulemaking or, where the proposal stage is bypassed, final rulemaking in the Federal Register; not explicitly mentioned are the discussions with other interested agencies, such as the Forest Service, or possible clearance in the Office of Management and Budget, which also occur before the proposal is ever made public. The twenty-step routine is not simply a formal checklist, as might attend the last few moments before a space flight; many of the steps involve conferences or clearances in which policy judgments affecting the ultimate shape of the proposal will 
The procedures themselves do not reflect any policy determination as to when rulemaking is the preferred mode of policy articulation, unless general disfavor can be inferred from the obstacles imposed. But conversations with departmental and Bureau staff invariably reflected awareness of those obstacles and, incleed, a resulting distaste for rulemaking. ${ }^{59}$

Part of the sense of hopelessness about invoking rulemaking seemed to be caused by the failure of those up the line to respond in prompt or meaningful fashion to suggestions made from below. Proposals would be lost, put on the back burner, or rejected without explanation. Obviously, not every suggestion. not even most that filter up from the ranks, is worth acting upon; but all might be worth a direct, prompt and understandable statement of reasons why the proposal is inappropriate, or what action will be taken on it. A Bureau office's file on one suggestion for change in regulations stretched over eleven months without any direct response to the suggestion from the Washington office; some changes in those regulations eventually were proposed, but the proposals were not concerned with the problems which had prompted the inquiry or the suggestions made for resolving them.

There are, of course, occasions when rulemaking is deliberately undertaken. A new statute which requires implementation does not present a choice between rulemaking and other forms of policy formulation; rules are required, although they are not always speedily forthcoming. Once a given block of rules exists, moreover, the Department follows a policy of periodic review of the whole. ${ }^{(i)}$ If a matter is not originally included in such a block, however, its allocation to other forms of policy elaboration is unlikely to be closely reexamined. Outside of the "budgeted" items-new statutes and periodic revision-the process of allocation seems quite unconscious: in that unconscious process, the obstacles to rulemaking hit with full force. It is not that some supervisory figure in the Bureau or the Department makes a conscious choice that a proposal is appropriate for rulemaking or some other mode, for

be made. Each change, it need hardly be added, provokes further discussion up and down the line. Cf. Loevinger, Book Review, 68 CoLum. L. REv. 371, 377-79 (1968), for a particularly emphatic, even mathematical, analysis of the over-consultation problem.

59. Thus, an official in one office stated:

We are not a pioneering agency .... we want to try to stick to the good old steady tried and proven ways. . . [We tried rule making on one occasion and] it never got anyplace. . . We at this level, this lower level here, we just don't pioneer things other than making suggestions, and we have made suggestions-we have made suggestions on changing our regulations that haven't been promulgated.

An official in another office similarly complained:

We have made proposals from time to time. Frequently we get the argument, on specific proposals, that the problem should be approached overall; then we do that, with encouragement, and it seems there is always some reason that radical changes aren't made. We are given more freedom and there is less control in handling litigation. The Department is so damn busy with day-to-day emergencies that it can't handle, that no one can pay attention to what we are doing in litigation.

60. C. MCFARLAND, supra note 11, at 260 n.103. 
no standards are articulated by which that choice might be made ${ }^{61}$ rather, individuals with an idea, making a choice of the means by which they might seek to put it into effect or the effort that its adoption will take, choose one channel rather than another, or are discouraged entirely, on the basis of the obstacles they perceive.

The Bureau's internal procedure for producing sections of its Manual is not much less complex than that required for rulemaking: ${ }^{62}$ Although no publication of proposed Manual sections (with attendant opportunity for public comment) generally occurs, and clearance with other parts of the Department or outside agencies such as the Forest Service is less formal (although it does occur if others will be affected), a multi-layered bureaucratic procedure must still be followed. A suggestion for new Manual sections or temporary directives may arise, whether from the field, from monitoring difficulties under existing guidelines, or from the promulgation of new regulations which must be implemented. An assignment to draw up the sections is made, generally far enough in advance to be part of the annual work plan for the office concerned; that assignment must be cleared within that officegenerally, the Bureau's Denver Regional Service office-and within the Bureau's Washington office, at least at the Assistant Director level. When the assignment is made, the Washington office forwards a statement of the policies it wishes reflected in the end product to the regional office. ${ }^{63}$ That statement itself is necessarily the product of considerable discussion and compromise. The regional office then consults with interested state offices, and produces a draft which is circulated to all state offices for comment. A final draft is ultimately produced and sent to Washington, where it is closely reviewed at several levels for policy and feasibility, and shown to other possibly interested agencies. In addition to approval at each level within the Resources Division, the draft must be approved by one office responsible for "coordination" and another responsible for format and style before it reaches the Director for final approval. The total effect, again, is a routing so choked with obstacles that few proposals survive in recognizable form; and staff members facing the prospect of creating policy through Manual revision consequently view the assignment as Sisyphean.

61. Nor is it clear that the effort to articulate them would necessarily result in more frequent or more rational use of rulemaking, rather than another bureaucratic hurdle further discouraging its use.

62. The problem of inclusion in the Manual of matter more properly set forth in regulation form is discussed at text accompanying notes 29-42 supra.

63. For example, in connection with the pending directives implementing the new regulation governing periodic work required to maintain a claim, sec note 55 supra, the Washington office might inform the Denver office whether the Bureau wished lapses in work occurring before the regulation was adopted to be taken into account, or whether its principal goal was to avoid further processing of claims which could be defeated on the work basis alone. 


\section{B. Public Participation in Rulemaking}

Although exempted by statute from the notice and comment requirements of the Administrative Procedure Act when its rules relate to "public property," any important public lands matter.$^{65}$ Notice of proposed rulemaking appears in the Federal Register; an opportunity for comment is given; and the rules, when they finally appear, are attended with a summary of the comments received and the departmental responses to them. On occasion, when the matter has seemed likely to be controversial, or comments have shown it to be such, public hearings have been held. These are never hearings on a record, nor are there formal criteria for invoking them; the Department appears to value hearings more for reasons of public relations than for any added contribution the opportunity to comment may make to the deliberative process. ${ }^{\theta}$

Similar procedures are followed in connection with proposed withdrawals of lands from the operation of the mining laws. While such proposals do not present issues of general policy - the question invariably is whether particular land shall be closed to future mining claims - they are made significant by the antiquity of the General Mining Law, for the statute does not permit the Department any measure of control over the manner in which prospecting or development is carried out on public lands, save for minor restrictions on surface use. ${ }^{67}$ Consequently, when the possibility of conflict between mining use and another intended use looms, the Department must make a choice between one or the other; it does not have regulatory authority to mediate the possible conflict, such as may be accomplished through leases. ${ }^{68}$ The choice

64. 5 U.S.C. \& 553(a) (2) (1970).

65. Various histories are given of the policy, but all are in agreement that it was substantially in effect by the late 1950's. Parriott, supra note 44, at 442-43; McCarty, supra note 21 , at 171 ; C. MCFARLAND, supra note 11 , at 245,261 n.108. A similar policy has recently been adopted for all departmental rulemaking. Compare 36 Fed. Reg. 8336 (1971) with 1 Administrative Conference of the United States, Recommendations AND REporTs, ACUS Rec. 16, at 29, 305 (1971).

66. This characterization seems particularly apt with respect to the hearings occasionally held to consider proposed withdrawals-proposals which are treated as rulemaking in most respects. For withdrawals, formal criteria for invoking hearings do exist, V BLM, Manual \$ 4.1.17; C. Wheatley, Withdrawals and Reservations of Public Domain LANDS 404-05 (1969). But the most frequent rationale for a hearing expressed in interviews was not controversiality, but that it would tend to earn good will for the Bureau in the community, put added force behind the proposal, or the like. Indeed, the one recent, straightforward issue of policy under the mining laws dealt with by rulemaking-the assessment work rule, note 55 supra - was quite controversial, as could have been predicted, but elicited no public hearing. See Sherwood, Improvement of Mining Claims, 18 RockY MT. Min. L. InSt. 149, 169-71 n.93 (1973).

67. United States v. Kosanke Sand Corp., 12 I.B.L.A. 282, 3 Environ. L. REP. 30017 (1973). Under 30 U.S.C. \& 612 (1970), surface resources not needed for mining purposes are reserved for the United States, but the United States is enjoined from interfering with the miner's reasonable use, rather than vice versa. Cf. 36 C.F.R. \& 251.12 (1973) (Forest Service). The point is not lost on representatives of mining interests. See, e.g., Ferguson \& Haggard, Regulation of Mining Activities in the National Forests, 8 LAND \& W.L. REv. 391 (1973).

68. The Mining Claims Rights Restoration Act of 1955, 30 U.S.C. \& 621 (1970), 
is dramatized by the result; closing the land to mining implies giving up any mineral resources there. Unlike trees or forage, they cannot be transplanted to another location. While the decision to withdraw lands from mining, whether by withdrawal or classification, is emphatically one the Government may structure as it chooses (involving as it does the use to which its own lands are to be put) ${ }^{69}$ few would wish by creation of a picnic ground or other socially insignificant use to foreclose development of a second Homestake mine. The Department thus acknowledges the importance of conducting an inquiry about the mineral potential of the land, and of having news of that inquiry reach persons who might be able to assist it. ${ }^{70} \mathrm{Here}$, too, hearings are occa-

makes an unsatisfactory stab in the direction of regulation for a limited class of lands (those possibly valuable for power plant sites), and thus illustrates the Secretary's usual powerlessness. Within 60 days after notice of a mining location on potential power site land is filed with him, as required by $i d . \$ 623$, the Secretary may hold a formal hearing on the question of whether mining operations would interfere with other uses of the land. His authority is limited, however, to three possible courses of action. He may forbid mining, permit it, or permit it under the single condition that restoration of the surface after mining be guaranteed. See United States v. Bennewitz, 72 I.D. 183, 187-88 (1965). Even in wilderness areas, statutory authority is limited to "reasonable" regulation of ingress and egress, 16 U.S.C. $\$ \$ 1133$ (d) (3), 1134(b) (1970); the Secretary does not have the authority to regulate the manner of mining in a claim once established. See Ferguson \& Haggard, supra note 67 ; but cf. 39 Fed. Reg. 31317 (1974) (Forest Service).

69. When Congress has directly authorized the Secretary of the Interior to withdraw or classify public lands, it usually has provided that such actions would not suspend operation of the mining laws on the affected lands. Pickett Act, 43 U.S.C. \$\$ 141-42 (1970); Taylor Grazing Act, 43 U.S.C. \& 315 (1970). Under the now-expired Classification and Multiple Use Act of 1964, 43 U.S.C. $\$ 1418$ (1964), the Secretary was empowered to classify land to be retained in federal ownership for use exclusive of mining, but that Act required publication of proposed classifications in the Federal Register with an opportunity for comment, at least for areas larger than four square miles. Compare 43 U.S.C. \& 1412 (1969) with id. \& 1414. Such classifications were thus virtually indistinguishable from withdrawals.

Withdrawals under these acts are said to be temporary in nature, classifying the land for a particular use for a possibly limited span of years, or protecting them from acquisition while legislation affecting them was sought. But see Raymond P. Heon, 76 I.D. 290 (1969); Buch v. Morton, 449 F.2d 600 (9th Cir. 1971). Nonetheless, to effect withdrawals that are "permanent" in nature-for example, because a lighthouse or airport will be built on the land withdrawn from mining - the Secretary has long asserted that he can suspend the operation of the mining laws, exercising an inherent executive power of withdrawal. This assertion has received both executive and judicial acceptance, Withdrawal of Public Lands, 40 Op. Att'y Gen. 73 (1941) ; United States v. Midwest Oil Co., 236 U.S. 459 (1915) ; United States v. Consolidated Mines \& Smelting Co., 455 F.2d 432, 444-45 (9th Cir. 1971), but remains a subject for dispute. Some still seem to contend that the passage of the Pickett Act, with its express denial of withdrawal power in the mining context, served to limit the "inherent" power affirmed, with regard to earlier withdrawals, by Midwest Oil. C. WheATLEY, supra note 66 , at 453-67. While Buch and Consolidated Mines show that this view has not prevailed, there remains a fair degree of congressional sensitivity to "unsupervised" executive withdrawals as trenching on an inherently congressional domain. E.g., PLLRC REPORT, supra note 5, at 42-44, 52-56.

70. The Department and Bureau have adopted policy guidelines for the process, which are stated in part in departmental rules - and in somewhat more elaborate form in the respective manuals. 43 C.F.R. $\$ \$ 2350,2450$ (1973) ; U.S. DEP'T OF THE INTERIOR, MANUAL $\$ 603.1 .1$; V BLM, Manual \$ 4.1.3, at 16; see C. Wheatley, supra note 66, at 387-90. The regulations are directed chiefly to applicants, instructing them how to apply and indicating that applications should be kept to a minimum; the general public is told little about the standards to be applied, or the information that might influence the decisional process. "[T] he problem of the nonfederal party is more than a mere burden of proof-it is a matter of not knowing what issues are viewed by officialdom as the critical ones." C. MCFARLAND, supra note 11, at 166. Cf. Reich, The Public and the Nation's Forests, 50 Calif. L. Rev. 381 (1962). 
sionally held, where public interest in the proposal appears to warrant that step. $^{71}$

The intensity and caution of the Department's in-house procedures have their impact, however, on the role public comment plays both in the writing of rules and the determination of withdrawal questions. The initial proposal is the product of such careful deliberation and hard-fought compromise that little patience or incentive exists to deal with the public comments that may be received. Already the outcome of the politics of consensus, it does not easily admit of later adjustments. The public is involved in form, but not in substance, in the formulation of rules.

This problem is especially pronounced when the prior consultations have included advisory bodies. The Bureau makes extensive use of advisory committees, which tend to represent local and industrial-user interests more than national or conservation interests. Use of these groups as informal sources of information and recipients of public relations gestures is undoubtedly beneficial; however, formal consultation with them in advance of rulemaking tends to make proposed rulemaking even less tentative when finally made public, and thus doubly deprives unrepresented groups of an opportunity for equal comment. Such groups are not heard as often, and they are not heard at a truly formative stage. ${ }^{72}$

In the withdrawal context, the influence of the public stage of the procedures is also reduced by other factors. Once public response to the proposal has been received, the Department's regulations call for a process of negotiation and adjustment between the Bureau and the agency seeking the withdrawal, to reduce the area to be withdrawn to the essential required and to protect

71. See note 66 supra. Many of the values of a hearing could be assured, however, without actually holding one, if the Department were to make internal studies bearing on proposals available for inspection, extending the comment period where necessary to permit response to these materials. An example may explain the need: in considering proposed withdrawals, the Department has before it both public commentary on the proposals and a mineral survey of the area by one of its mining engineers. Since the Department's own survey is sparked by the same events as prompted publication of the notice of the proposal, the survey report is not usually completed before the end of the initial comment period. The Department regards postponement of the public comment period to await the survey as undesirable, since that would delay the appearance in the Federal Register (although not the land office records) of notice of the protective segregation of the lands which had taken place. Nonetheless, because the report might influence the views of commentators, as well as the Department, about the advisability of the withdrawal, and perhaps improve the deliberative process, the Department should make provision for public input after completion of the survey report, even if this entails an extension of the comment period. This is further trouble, to be sure, but it is probably less inconvenient than an oral hearing. Any added delay would not usually be a significant factor in the Department's deliberative processes; where speedier action is required, that fact would warrant, as it already does, more peremptory action.

72. See Hearings on H.R. 7211 Before the Subcomm. on the Environment of the House Comm. on Interior and Insular Affairs, 92d Cong., 1st Sess., ser. 92-20, at 198 (1971). The susceptibility of the private stages of the process to influence and obstruction gives reason to challenge those who have seen rulemaking as a particularly democratic form of policy formulation. Cf. K. DAvIs, supra note $37, \$ 6.16$. 
other uses to the maximum extent possible. ${ }^{73}$ The outcome is a report of proposed findings and action, which is given to the applicant agency; if unacceptable to it, the report may be put before the Director of the Bureau, the Secretary, and-for applicants outside the Department-the Office of Management and Budget for review. ${ }^{74}$ This review procedure is said to be little invoked, because in practice the Director and the Secretary exercise little supervisory power over agency requests for withdrawals. ${ }^{75}$ What is noteworthy about the negotiation, adjustment and review process, however, is the exclusion of the interested public; no participants in the comment proceedings are shown the Bureau's proposed action or permitted to seek its review within the Bureau and Department. Although treated as interested parties at one stage of procedure, members of the public are kept from participation when, because the record of investigation is complete and the proposal for action has been drawn, their comments might have their greatest impact. ${ }^{76}$

This restricted role for public input, together with the immediate and often indeterminate segregation of lands from application of the mining laws once a proposal for withdrawal is made, appears to be generating pressure for creation of a preliminary procedure in withdrawal cases like that followed in rulemaking, in which some interested parties are contacted and their views informally solicited before any formal proposal is made. Thus, an official of a large mining company speaks of developing good relations with Bureau (and Forest Service) personnel in the areas in which it is interested, in order to learn in advance of lands possibly marked for segregation and to attempt to delay action on proposals until it has had a chance to evaluate the prospects there. ${ }^{77}$ The Bureau shows an increasing tendency to seek mineral reports, at least of a preliminary nature, as part of any proposal for withdrawal; and its personnel refer to relationships with local mining associations or others which permit them to check out in advance the degree of interest in certain lands.

There is nothing venal about consultation before decisive steps are taken; in a quasi-rulemaking, heavily discretionary setting such as this, it seems like good sense all around. Nonetheless, as in the case of departmental rulemaking generally, the result may be to cheapen the ostensibly public procedures by encouraging all compromises to be made in advance-and to be made in a

73. 43 C.F.R. \& 2351.4(c) (1973); for withdrawals to meet Bureau needs, of course, this process is a wholly internal one.

74. Id. \& 2351.5.

75. C. WheATLEy, supra note 66 , at 485 .

75. See text accompanying note 71 supra; cf. Wagner Elec. Corp. v. Volpe, 466 F.2d 1013 (3d Cir. 1972).

77. He concedes the expense of the effort, and remarks:

The small miner, who can't keep his ear to the ground, wakes up one morning and finds the land noted, and he hasn't finished his borehole yet. It is not a good system or an equitable one. Even major mining company geologists may not know-and oughtn't to have to spend their time trying to find out.

Cf. Reich, supra note 70, at 387-89. 
setting in which only local and commercial interests are likely to participate. ${ }^{78}$ If the public process is put forward as the setting through which adjustments will be made, it is wasteful and misleading to permit it to be duplicated by a more covert process, to which only some segments of the affected public are permitted access.

\section{The Unintended Advantages of Adjudication}

The controls over adjudication are far less rigorous, from the perspectives both of initiation and of ultimate policy control, than the controls over legislative policymaking in the Department. To consider the formulation of litigation strategy first, minor innovations or variations appear to be possible with little or no supervisory control at all: a mineral valuation specialist with a fresh idea about formulation of the "discovery" standard may simply draw up the charges against the validity of a mining claim as he believes they ought to be drawn; the attorney in the Regional Solicitor's Office arguing the case writes his brief for the proceeding before the administrative law judge with little supervision inside his office and none outside it. Obviously in each case the cooperation of others may be required at a later point-the mineral valuation specialist hopes that the attorney handling the complaint once it is answered, if it is answered, will adopt his theory; the attorney depends on acceptance of his approach, in the first instance, by the administrative law judge and, then, by his superiors in the Solicitor's Office in Washington should there be an appeal. But despite these contingencies, and the very large possibility that any litigation will wash out before the desired change is achieved, the lower employee has a power of initiation and control which he feels he lacks in rulemaking or manual production; the initial shaping is his.

Even major efforts to shape policy by litigation need not pass so many points of potential derailment, nor so submerge individual initiative as the legislative forms of policymaking appear to do. A prominent example is the turnaround in handling applications to patent oil shale claims which occurred during the summer of 1960 . For the previous twenty-five years or so, the Department had been rather freely issuing such patents; however, as the value of the land became clearer and the connection between the applicants and the original-and often, it appears, somewhat fraudulent-locators became more remote, officials in the field grew increasingly disturbed over the practice of unrestricted patent issuance. Because an overruling of settled policy was required, Washington's permission was mandatory. Arguably, rulemaking could have been used, but one's impression is that it was never seriously considered; permission for a litigation campaign, unlike rulemaking, required no agreement over a particular form of words. Policy approval had to be

78. Cf. Note, Managing Federal Lands, 82 YALE L.J. 787 (1972). 
obtained-that is, the approval of the Secretary, after such consultations as he felt were required-and that took several efforts $;^{79}$ but there was no need to traverse the whole bureaucracy, and once the approval was obtained, implementation of the plan was very much a matter of individual effort.

Moreover, any adjudicatory setting carries with it an urgency often lacking in the rulemaking context: a specific reclamation project awaits the clearing off of invalid mining claims before construction can begin; a particular application is pending and requires action. The Department has often, and validly, been accused of delay in its adjudicatory processes-a problem which appears to be coming under greater control; but the allure of postponement for another day is nonetheless diminished where a specific case unavoidably requires decision. ${ }^{80}$ In the legislative context, similar impetus is felt only when a new or amended statute requires implementation, or some new judicial interpretation requires a restructuring of existing rules or guides. The Geothermal Steam Act of $1970^{81}$ was such an event; after three years of preliminary efforts to formulate basic policy under the National Environmental Policy Act, regulations have just recently been adopted. ${ }^{82}$ Absent the impetus of a statute that cannot otherwise be administered (and an energy crisis which might be alleviated by the resources at issue), progress would be truly glacial.

\section{A Complicating Factor: Bifurcation of the Rulemaking and Adjudicatory Function}

\section{A. The Board of Land Appeals}

The allocation of the interpretive function between rulemaking and adjudication is difficult enough under ordinary circumstances. This task has been complicated by the Department's creation of the Office of Hearings and Appeals as an independent body to perform the adjudicatory function, essentially free of secretarial or other department control, while rulemaking continues to be performed by the Department's operating divisions under the watchful eye of the Solicitor's Office. Formerly, the Solicitor's Office sat astride both the rulemaking and adjudicative aspects of interpretation, permitting rather tight and unified control over departmental policymaking. The Solicitor's Office retains substantial influence over rulemaking, coordinating and supervising efforts at the departmental level, and consequently is able to influence rule

79. Hearings on Oil Shale Before the Sen. Comm. on the Interior and Insular Affairs, 89th Cong., 1st Sess. 40-41 (1965).

80. See McFarland, supra note 49 , at 42 . As he remarks, this is by no means a peculiarity of the administrative process.

81. 30 U.S.C. \$\& 1001-1025 (1970).

82. Original draft proposals were published in the Federal Register in July, 1971, 36 Fed. Reg. 13722-40. Revised proposals were published in November, 1972, 37 Fed. Reg. 25282-313, and July, 1973, 38 Fed. Reg. 19748-79, without any indication either of the changes made in the proposal or of the specific reasons for making them. Final regulations appeared in 38 Fed. Reg. 35068 (1973). 
content significantly. ${ }^{83}$ It no longer exercises any decisional control, however, over litigation. The Department's adjudicatory law is now entirely committed to administrative law judges and administrative appeal bodies of the Office of Hearings and Appeals. One of those appellate tribunals, the Board of Land Appeals, is responsible for final decision in all cases involving disputes under the mining law.

The Board of Land Appeals' internal procedures ${ }^{84}$ do not seem well adapted to the role of making policy through adjudication. When appeal documents are complete, an administrative officer selects a panel of three members, making his selection on a random basis adjusted only for even distribution of workload or the occasional case in which the Director designates himself as a member of the panel. Oral argument is rare, limited to cases in which a request is made and even then a matter for discretion. Rather, the documents are sent to one of the designated panel members, and he and a staff assistant write an opinion in the case. No formal consultation with the other two members of the panel is provided for, and none usually occurs. A predecision conference will be held only if the opinion writer wishes it. The opinion, when complete, is sent to the other panel members with the supporting documents; they may propose changes, note their agreement, or prepare opposing opinions. Each opinion is circulated to all members of the Board for possible comment, dissent, or invocation of en banc consideration before release. Even in en banc cases, the same dry procedures may be followed.

The problem here is that the Board's cloistered approach may lead, in the routine case, to unnecessary and even misleading opinions; in more important cases, to a failure to focus sharply on the matters in issue. Of course, appellate bodies, notably the federal courts of appeal, increasingly dispose of appeals without oral argument, as one means of dealing with the quickening pace of their business. But no court of appeals contemplates decision before argument where there is significant controversy or where the outcome will have any shaping impact upon the law ; typically, the unargued appeals are those in which any opinion is cursory and designated for the dustbin - neither to be published nor relied upon in any future litigation involving different parties. But for the Board, the panel member who initially receives an appeal must write fully even if the case appears insignificant, since his colleagues' views are not yet known. Moreover, the Board neither identifies its uncontroversial holdings

83. This function does not differ materially today from the description of the rulemaking responsibilities of the Solicitor's office given by the Attorney General's Committee on Administrative Procedure in 1941. Report of the Attorney General's Committee on Administrative Procedure in Government Agencies, S. Doc. 8, 77th Cong., 1st Sess. $69-70$ (1941).

84. A brief description of the Board's operations by the first director of the Office of Hearings and Appeals appears in Day, Administrative Procedure in the Department of the Interior: The Role of the Office of Hearings and Appeals, 17 Rocky MT. Min. L. INST. 1, 1-11 (1972). 
with brief opinions and instructions not to publish or cite them, nor limits perfunctory, record-only review procedures to such cases; the opinions seem equally elaborate and the deliberative processes seem equally remote in all cases. If a case is cut-and-dry under departmental precedent and rules, oral argument is indeed a waste; but so is seriatim consideration, the writing of lengthy opinions, or any indication that those opinions may be significant for the Department's future business. It would be equally suitable, and fully sufficient against the possibility of judicial review, for the panel to agree after review of the record that no real controversy exists and to issue a judgment to that effect, adopting the findings and conclusions made below.

Where significant controversy exists, on the other hand, the Board's policymaking responsibilities suggest that it should grant oral argument ${ }^{85}$ rather than discourage it. ${ }^{86}$ Here, the dryness and remoteness of its procedures contrast sharply with the Board's authority to reformulate significant policywithout any institutionalized check beyond the possibilities of reconsideration or, more unlikely, secretarial review. ${ }^{87}$ Without oral argument and the initial collegiate consideration that it implies, the individual members of the panel never face the discipline of preparing for argument at a particular time; do not experience the sharpening focus of adversary presentation of central issues; and have little sense of post-consideration agreement regarding the simplicity or complexity of the issues presented. The infrequency of oral argument may encourage respondents not to file briefs on appeals, and lead the non-writing Board members-busy with their own work-to give somewhat unfocused attention to the case. Collegiate consideration could produce both an accelerated pace of decision from filing to judgment and deeper, more sharply focused consideration where controversy is genuine.

\section{B. Secretarial Control over Board Decisions}

Particularly striking is the absence, even in cases in which significant policy questions are presented, of any explicit provision for secretarial control over the Board's policy conclusions to assure coherence and intelligibility in the Department's interpretive application of the mining laws. The Board, like the Office of Hearing and Appeals generally, was created in response to the pressure of criticism from the private bar that policy and adjudication functions in the Department were too closely linked; with its creation, division of func-

85. Compare 43 C.F.R. \& 4.25 (1973) (Board of Land Appeals; oral argument discretionary), with 8 id. \& 3.1 (d) (1-a, e) (Board of Immigration Appeals; oral argument mandatory on request unless appeal is frivolous or technically deficient).

86. Oral argument is doubtless discouraged by the 1500 -mile distance from where the Board sits to the nearest mining district or significant concentration of public lands, requiring at least one of the parties to hire local counsel or fly half the continent or more to attend. Relocation of the Board to one or more of the western law centers, a step apparently under consideration in the Department, would markedly alleviate this problem.

87. See notes $92-94$ and accompanying text infra. 
tion became complete ${ }^{88}$ Members of the Board, although typically drawn from within the Department, are almost completely isolated from contact with the rest of the Department once on the Board. Their offices are located in suburban Virginia, several miles from the main departmental complex in Washington, D.C. The point is strongly made in the Department's regulations that Government counsel appearing before the Board of Land Appeals "shall represent the Government agency in the same manner as a private advocate represents a client," "89. and that there shall be no oral or written ex parte communication between "any" party and a member of the Office of Hearings and Appeals concerning the merits of a proceeding. ${ }^{90}$ The result of these procedures is that departmental officials can argue policy matters-the desirability of overruling outdated or erroneous departmental precedent, for example-only through their briefs. The general operating divisions of the Department have no control over the outcome and cannot impose their policy preferences, except by previous adoption of a rule. ${ }^{91}$

The isolation of the Bureau of Land Management, ostensibly the principal source of policy concerning mining matters, is particularly dramatic. Before creation of the Office of Hearings and Appeals, the Bureau played a decisive role in litigative as well as in legislative approaches. Provision for an intermediate appeal to its Director from the hearing examiner's decision permitted the Bureau a measure of policy control. The Bureau's function as intermediate appellate body was eliminated, however, because it was viewed as a source of oppressive delay and an example of the combined functions which the proponents of reform believed must be separated. The result was isolation of the Bureau from any contact with a case once a complaint had been made and answered (and, perhaps, evidence had been given by Bureau experts). While rules and Manual directives come into being through the Bureau's labyrinthine corridors, the prosecution of litigation is entirely in the hands of the Solicitor's Office; adjudication, with its policy overtones, belongs to the Office of Hearings and Appeals and its Board of Land Appeals. To the extent policy in mining matters is made by decision rather than rule, the higher levels of the Bureau no longer contribute significantly to its formulation.

To be sure, the independence of the Board, like other tribunals of the Office of Hearings and Appeals, is not withou formal limit; the Secretary retains his power of personal decision. ${ }^{92}$ The regulations, however, make no

88. 35 Fed. Reg. 12081 (1970). The history and criticisms are briefly recounted in Day, supra note 84, at 1-8; see e.g., PLLRC REPORT, supra note 5, at 253; McCarty, supra note 21 , at $172-74$.

89. 43 C.F.R. \$ 4.3 (b) (1973).

90. Id. \& 4.27 (b).

91. Although the issue has not been squarely tested, members of the Office of Hearings and Appeals feel they can disregard lesser policy statements, such as Manual directions and Solicitor's Opinions, if convinced of another interpretation.

92. 43 C.F.R. \& 4.5 (1973). 
formal provision for secretarial review; rather, they state that no departmental appeal will lie from a decision of an appeals board. ${ }^{93}$ Even if that provision, important to assure finality of administrative decision before judicial review is sought, were not seen to preclude a corrective, personal secretarial action, such intervention would be extraordinarily difficult as a political matter, flaunting the very pressures that led to creation of the Office; the Secretary could intervene only in the most urgent cases, if at all. In fact, the Secretary has not yet intervened, although departmental demands for rehearing have been frequent enough and the Solicitor's policy arguments have often been rejected by the Office.

Certain informal lines of communication do exist-incursions, perhaps necessary ones, on the spirit if not the letter of the rule that the Department appears before the adjudicatory body "as a private advocate." Private communications between the Department and the Director of the Office, who does not ordinarily sit on appeals, have been quite free. While there is some debate whether he is ever approached on the merits of policy matters, the Director will be told if a particular matter is regarded as "important," and is occasionally asked either to have matters considered en banc or to place himself, ex officio, on the panel. The effect is to underscore the policy implications of the particular case. Communication exists as well in the opposite direction: ${ }^{94}$ departmental regulations or forms which by their obscurity have proved particularly productive of litigation are called to attention, sometimes with suggestions for changes that might produce greater clarity or otherwise reduce the litigative workload. And the opinions themselves, concrete examples of the Board's independence, may produce a somewhat greater incentive at higher levels in the Department to act by rule.

The total picture, however, remains quite different from one's ordinary expectations about the choice between rulemaking and adjudication. Instead of a single decider, rationally or irrationally allocating choices between the two procedures and itself making the fundamental policy decisions whichever mode is chosen, one finds a frequently unconscious process of allocation and, more important, a process which leads ultimately to different authorities. Whatever its deficiencies as a maker of rules, the National Labor Relations Board which makes a rule is the same body as that which, encountering a troublesome point in litigation, announces a new departure in that format. For the Department

93. $I d$. § 4.21 (c). Reconsideration or hearing en banc is provided for, and the filing of a motion to that end would permit the Secretary to intervene were he so inclined.

94. Cf. Day, supra note 84 , at $3-5,23-24$. It must be emphasized that the only suggestions made of contact between the Office and general operating divisions of the Department relate to matters of policy and interpretation; on questions of fact and of rule application, no basis whatever exists to suspect that the independence of the Office has been compromised. It would be surprising were there even an effort in that direction. But the point about policymaking by adjudication, which warrants the present excursus, is that it permits "judges" to announce decisions which could equally be made in a legislative format. 
of the Interior, on the other hand, the procedural choice-rule, Manual, Solicitor's Opinion, or decision-determines the body which makes the policy decision as well as the format in which that decision appears. The effect is "to isolate the Secretary and others within the Department most concerned over policy from any feel for the impact of the flow of decisions on policy,"95 and to fragment the policy function.

The Office of Hearings and Appeals and its Board of Land Appeals thus depart substantially from the considerations which underlay the recommendation of the Administrative Conference in 1968, that agencies "having a substantial caseload of formal adjudications should consider the establishment of . . . intermediate appellate boards ... with discretionary authority in the agency to affirm summarily or to review [their decisions] ...."96 In the recommendation and, particularly, Professor Freedman's perceptive report underlying it, ${ }^{97}$ insistence on the mechanism of discretionary review makes plain that promoting coherence in agency policy formulation is central. Although reduction of delay, elimination of unwarranted litigation costs, and the possibly enhanced appearance of fairness resulting from removal of strictly routine adjudication to a body without significant overall policy responsibilities were also anticipated as benefits that would flow from creation of a separate appeals body, "the failure of the federal administrative agencies to achieve the formulation of coherent policy" 98 was a focal concern.

Professor Freedman suggested two possible models for such boards: (1) a "judicial" board limited to applying existing rules and precedents and required to certify policy issues of first impression to the agency head; and (2) the "administrative" model-apparently rejected by the Conference in its recommendation-in which a board conceded a role in formulating policy would be permitted to wield the full range of policymaking tools, rules as well as decisions, but would remain subject to formal, discretionary review at higher levels of the agency. While these models are neither polar nor exhaustive, the Board of Land Appeals lacks the significant features of both: unification of the policymaking function, and ultimate control, through discretionary review, in the agency's head. Although impartiality in the application of established

95. Bloomenthal, supra note 21 , at 257 . The problem here is not significantly different from that often predicted in response to recommendations for radical separation of adjudicatory and legislative functions in the major federal agencies. E.g., Loevinger, supra note 58; Robinson, supra note 4, at 485-86.

96. 1 Administrative Conference of the United States, Recommendations and REPORTS, ACUS Rec. 68-6, at 20, 125 (1971); see also Statements of the Administrative Conference on the ABA Proposals to Amend the Administrative Procedure Act, 19721973 Ann. Rep. 51 (1973).

97. Freedman, Review Boards in the Administrative Process, 117 U. PA. L. REv. 546 (1969).

98. Id. at 547. It is hardly necessary to call again the roll of those have decried this failing. But transplantation of adjudicatory authority to an "independent" body has not usually been thought the cure. Cf. Robinson, On Reorganizing the Independent Regulatory Agencies, 57 VA. L. REv. 947, 970 (1971). 
rules is essential, it seems an arid concept of fairness that purchases independence of function at the cost of coherent policy. Creation of the Board has heightened the need to develop techniques for assuring coherence and intelligibility in the Department's interpretive application of the mining laws.

\section{An Illustration: "Discovery"}

These generalizations may be illustrated by a consideration of the principal criterion by which the Department tests the validity of mining claims under the General Mining Law, whether a "discovery" of a "valuable mineral deposit" has been made. The requirement of discovery of a valuable mineral is imposed, but left undefined, by sections 1 and 2 of the General Mining Law. ${ }^{99}$ Subsequent statutes, notably the Mineral Leasing Act of $1920^{100}$ and the Common Varieties Act of $1955,{ }^{101}$ have limited somewhat the types of minerals which may be considered "valuable" - coal, oil, and common sand and gravel, for example, may no longer be so considered-but have left unburdened by statutory provision such questions as how much ore, of what richness, must be found in the case of minerals which remain locatable. Any deposit of a "valuable mineral" no matter how weak the ore? Any "mineral deposit" which is "valuable" in the sense that the deposit could be sold in place, although it is not yet ripe for exploitation because richer ores remain available, technologies are undeveloped, or the like? ${ }^{302} \mathrm{~A}$ deposit which had greater value when found than it does at present, due to a change in market conditions? ${ }^{103} \mathrm{~A}$ deposit which reflects greater value than any other potential use for the land - say, for residential development or timber production ${ }^{304}$ A marginal deposit, but one found by a prospector, say, an established mining company, believed to have a good-faith mining purpose ?105

The view sometimes articulated, that these undefined terms present questions of law to be resolved through a judicial search for some fixed meaning, ${ }^{106}$ is untenable. When the Secretary or his delegate decides that discovery of a valuable mineral has been demonstrated, he issues a patent and the question of the claim's validity never reaches court; to that extent, final definitional power for the grant of patents and confirmation of claims has been placed with the administrator. Thus unable to fix the inner limit of meaning, a court can say only when the administrator has been too grudging. Realizing that it can rarely be called upon to say whether the Secretary has treated "discovery"

99. 30 U.S.C. $\S \S 22-23(1970)$.

100. 30 U.S.C. $\$ \$ 181-287$ (1970).

101. 30 U.S.C. \& 611 (1970).

102. See E.S. Larsen \& Minerals Trust Corp., 9 I.B.L.A. 247 (1973).

103. See Alvis F. Denison, 76 I.D. 233 (1969).

104. See Thomas C. Wells, A-30805 (Jan. 8, 1968); United States v. Kosanke Sand Corp., 12 I.B.L.A. 282, 3 ENVIRON. L. REP. 30017 (1973).

105. See New Jersey Zinc Co., 74 I.D. 191 (1967).

106. See, e.g., Reeves, The Origin and Development of the Rules of Discovery, 8 LAND \& W.L. REv. 1 (1973). 
as meaning too little, a court would be reluctant to conclude that he has construed it to require too much; one adjusts to the condition of hearing only one side of the argument. The Secretary has in fact been permitted substantial leeway in his definition of the statutory terms. ${ }^{107}$

The definition of "discovery" of a "valuable mineral deposit," changing over the years, has clearly been the instrument of policy. ${ }^{108}$ In early years, when the Government's lands were still viewed as goods held for disposal, securing a patent was easy and quick. More attention was paid to the accuracy of the cadastral survey that fixed its location on the public land records, than to any mineral survey to determine whether or not minerals had in fact been found. With increasing awareness that remaining public lands were a trust to be managed for the benefit of all, rather than an incubus or financial asset to be disposed of, and with increasing sophistication in the available technology for processing mineral ores, mineral surveys became more careful, and the standards applied, more rigorous. Patent applications have been slowed to a trickle both by the tightening of standards and by adoption of the policy of declaring invalid any claim for which a patent application is denied. ${ }^{109}$

The realization that lands ostensibly claimed for their mineral values were being used for residential development, timber production, summer homes, or long-term speculation, rather than developed as mineral properties, contributed as well to the tightening of the discovery standard. There were also practical administrative considerations: a rigorous, objective standard of discovery might appear more workable, less productive of expensive litigation and difficult questions of credibility or purpose, than a standard which sought to assess the element of good faith or mining purpose. The very age of the statute produced substantial strain; the statute lacks any express provision for ongoing regulation of claims, ${ }^{110}$ and so its definitional provisions have been made to serve functions for which supervisory measures might ordinarily be used. These functions, however, are at best imperfectly served, since the Department can only determine that a claim is or is not valid, not how it can best be developed consistent with other values. ${ }^{111}$

The current dispute over application of the discovery standard to oil shale is illustrative. This common mineral has long been seen as a rich potential

107. United States v. Coleman, 390 U.S. 599 (1968) ; Brubaker v. Morton, 500 F.2d 200 (9th Cir. 1974).

108. See the unusually forthright-and sound-statement in Hochmuth, Government Administration and Attitudes in Contest and Patent Proceedings, 10 RockY Mr. MiN. L. Inst. 467 (1965). See also Note, Government Initiated Contests Against Mining ClaimsA Continuing Conflict, 1968 Utah L. Rev. 102, 129-35; Nonfuel Minerals, supra note 12 , at 390-410, 419-20. In its most recent pronouncements, however, the Board has taken a rather limited view of the policymaking inherent in the process of definition. Kosanke Sand Corp., 12 I.B.L.A. 282, 3 ENviron. L. REP. 30019-21 (1973); United States v. Winegar, 4 ENviron. L. REP. 30005 (1974).

109. See note 15 supra.

110. See note 68 supra.

111. Kosanke Sand Corp., 12 I.B.L.A. 282, 3 Environ. L. ReP. 30017, 30019-21 (1973). 
source of petroleum products and, prior to enactment of the Mineral Leasing Act of $1920,{ }^{112}$ was subject to the mining laws. Under the Department's usual discovery standards, such claims could not qualify for patent, however, for the shale had no immediate commercial use. In a striking example of the flexibility with which the statute has been interpreted to achieve desirable objectives, the Department adopted-first by Solicitor's Opinion ${ }^{113}$ and then case decision $^{114}$ - a different standard of discovery for oil shale. To further the policy of fostering the development of this enormous energy resource, the Department abandoned the requirement that current value be established. The desired development, however, did not occur. But since the discovery standard change favored claimants rather than limited their assertions, a judicial test of its correctness was at best unlikely. ${ }^{115}$ Now, fifty years later, the pre-1920 claims continue to be asserted ${ }^{116}$ and if valid may result in development much less carefully constrained than is likely to occur under the Department's recently adopted leasing program. ${ }^{117}$ In a major reexamination of the issue, the Board of Land Appeals rejected the differential standard of discovery for oil shale as "clearly contrary to the mining law,"118 and determined that no qualifying discovery of a valuable mineral can be made without a showing of "present value." 119

Throughout the development of its discovery standards, the Department never attempted to state its construction in rule form. True, lengthy descriptions of "discovery" and "valuable mineral deposit" have been produced for the Bureau Manual-a format which ostensibly controls mineral examinations and the formulation of complaints and exercises substantial, if diminishing, influence over Department attorneys and adjudicators. And reading these formulations suggests some rather fine policy differentiations: ores of

112. 30 U.S.C. $\$ \S 181-287$ (1970). The Act required future interests in shale-rich lands to be acquired by lease, id. $\$ 241$, but saved - under conditions not important here, see Hickel v. Oil Shale Corp., 400 U.S. 48 (1970)-existing valid claims, 30 U.S.C. $\S 193(1970)$.

113. Instructions, 47 I.D. 458 (1920).

114. Freeman v. Summers, 52 I.D. 201 (1927).

115. No such test could have been brought by a public official. Sec text accompanying note 106 supra. Freeman v. Summers, 52 I.D. 201 (1927), was a private contest between Summers, an applicant for a homestead, and Freeman, asserting the discovery of oil shale. Summers was entitled to prevail only if the lands were not valuable for mineral exploitation. He lost because, under the then prevailing interpretation, they were found to have that value. The private contest setting made it theoretically possible that judicial review could have been obtained-if homesteader Summers were able to come to Washington (then the only possible venue for suits seeking relief from Department decisions) for the purpose, and assuming also that service over Freeman and his compatriots could be had there or that they would not have been considered indispensable parties. Sec C. McFARLAND, supra note 11 , at 186-87, 223-24 nn. 267-70. Not surprisingly, review was not in fact sought.

116. See Hickel v. Oil Shale Corp., 400 U.S. 48 (1970), on remand, 370 F. Supp. 108 (D. Colo. 1973).

117. See 38 Fed Reg. 33186 (1973) (prototype leasing program). (1974).

118. United States v. Winegar, 16 I.B.L.A. 112, 4 ENviron. L. REP. 30005, 30016

119. $I d$. 
valuable metals, such as copper or gold, are said not to require the same showing of present marketability as commoner minerals, such as limestone; for forested land, a mineral deposit must be so "valuable" that its exploitation is clearly the highest and best use of the land. But the standards lack force as a declaration of departmental or Bureau policy. Strikingly, they are not presented simply as statutory interpretations grounded in policy considerations; rather, each is supported by reference to numerous prior adjudications. To be sure, these decisions were rendered when insouciance about separation of functions permitted them to be made by persons in the main stream of administration; the Manual standards themselves were adopted after the excruciating bureaucratic procedures described above. ${ }^{120}$ Yet the effect of the citation format is to suggest that the standards are no more than a digest of the Department's case law. Consequently, they may be disregarded, treated as a secondary source if a rereading of the cases or analysis of subsequent cases suggests a different synthesis. In fact, that has been the fate of the Manual definitions. Unrevised in seventeen years, they are ignored.

Government officials who must apply the discovery standard in their work are well aware of its flexibility and policy implications, and use that flexibility within the limits imposed on them by staff review or current case law to achieve what appears to them to be useful change. Thus, a mineral valuation expert bases his recommendations for contesting claims on his belief about what the discovery standard ought to become as well as upon his understanding of what it is; should there be a hearing, he will work closely with the attorney assigned to the case, try to persuade him to his theory, and give the testimony necessary to frame the case. His reconmendations are supervised for conformity to Bureau policy, but supervision is undertaken by a colleague working in the same office, who is busy with other matters and permits a fair amount of initiative if only to maintain morale. The expert would not think of provoking a legislative type of process because that route is too impersonal and clogged with obstacles. Case work, on the other hand, involves dealing with a few well-known individuals, not a huge bureaucratic machine; it generally involves relations with peers or near-peers, not a belittling chain of command. The case is a matter of individual responsibility; one takes it as far as one can, then trusts it to the winds. A prototype rule cannot easily be so regarded. ${ }^{121}$

120. See notes $62-63$ and accompanying text supra.

121. Hochmuth, supra note 108. This possibility of individual initiative contributes to the prospector's fear of arbitrariness, as eloquently remarked by a Denver attorney:

The antiquity of the General Mining Law makes it less acceptable to staff in the field than it might once have been; today's. mineral examiner or field attorney is offended by the notion of J. Jones getting 160 valuable acres virtually for free, and the ghost of Albert Fall [Secretary of the Interior during the "Teapot Dome" scanda1], still stalking the Department's corridors, reinforces his disposition to resist. A tradition of decision by adjudication, in these circumstances, may permit 
The consequences of fractionating the policymaking function within the Department have begun to appear. Whether in expressing skepticism that they can be bound by Solicitor's Opinions or in making subtle changes in the discovery concept which seem to ease the most demanding of the recent interpretations, ${ }^{122}$ the members of the Board of Land Appeals assert an independence of other departmental policymakers which is at the same time intended and productive of possibly destructive antagonisms. ${ }^{123}$ Should the Board recant the existing policies on discovery, and as a result order issuance of a patent where none would have been granted before, no court will be called upon to judge whether it has interpreted "discovery" too permissively. Internal check of an unacceptable decision is possible, but only at the cost of destroying both the finality of the Board's decision and the appearance of impartiality which has been so emphatically sought after.

Permitting policymaking to continue as a predominantly adjudicatory matter under the present institutional arrangements assures a loss of control. The issue is not simply whether adjudication or rulemaking is the more suitable procedure to formulate policy, but who is to decide the policy question. The operating divisions of the Department have a necessary and, indeed, proper interest in having some assurance that the outcome of adjudication will conform to the policies of the Department generally; they naturally want and, they contend, ought to have more than a litigant's say. The Secretary's position vis-à-vis that office is not that of a coordinate and coequal branch. To the extent that it is not merely applying existing rules to disputed facts, the Board of Land Appeals cannot be insulated and impartial in its function without raising some risk of prejudice to the Government's proper interests in its lands. The interest in coherence cannot be wholly disregarded. If a concern for fairness to private litigants compels the insulation of the Board of Land Appeals from secretarial policy control, the Secretary must have some other forum in which to assert that a legal or, less likely, factual conclusion of the Board contravenes departmental policy.

\section{Rationalization of the Policymaking Function}

Whether an independent board to decide administrative appeals is a sensible institution is, itself, an interesting question. Both the Public Land Law Review Commission and its reporter on procedural matters, Professor McFarland, recognized the divided administrative responsibilities which.

efforts to develop new policy; my fear is that in a setting of marginal super-

vision, no one will get a claim if it can be helped.

See Carver, Administrative Law and Public Land Management, 18 A.B.A. Admin. L. Rev. 7, 14-15 (1965).

122. United States v. Coleman, 390 U.S. 599 (1968) ; cf. Kosanke Sand Corp., 12 I.B.L.A. 282, 3 ENVIRON. L. REP. 30017, 30019-21 (1973).

123. Letter from General Counsel, U.S. Dep't of Agriculture to Administrative Conference of U.S., May 28, 1974, at 1, 4, on file at Administrative Conference of U.S. 
would attend any independent review board; but both also stressed the public apprehension that disinterested justice could not be obtained, as possibly warranting steps in that direction. ${ }^{124}$ As has also been apparent in more general studies of the problem, ${ }^{125}$ the two considerations are not readily reconciled. Once the existence of the Board is assumed, however, the question becomes how to minimize the division in policy function.

\section{A. Mandatory Curbs on Adjudication}

The Public Land Law Review Commission's recommendation, already noted, ${ }^{126}$ was that the Department be prohibited from applying any standard or interpretation not previously embodied in a statute or departmental regulation against the interests of a party, and be required to make all changes in policy through the medium of rulemaking. ${ }^{127}$ This restriction of policy formulation to rulemaking responds directly both to uniform critical comment and to the bifurcated policy structure now established within the Department $;^{128}$ the restriction has the apparent support of the American Bar Association as well. ${ }^{129}$ What in effect is intended is a limitation of adjudicatory function to fact-finding and rule-application. But the judicial function can not be so limited-or, as Hamilton put the complementary proposition, rules must

leave room for accommodating to circumstances, which cannot, beforehand, be accurately appreciated, and for varying the course of proceeding, as experience shall suggest to be proper, and ... avoid the danger of those obstructions and embarrassments . . . to be apprehended from an endeavor at greater precision and more exact detail. ${ }^{130}$

The question is how complex or detailed a skeleton can be described in advance, how narrow the gaps can properly be made. Even with the most comprehensive "legislative" scheme, judicial application inevitably "makes" new law.

Nor is it clear that a requirement that all policy formulation be conducted through rules would amount to anything more than unenforceable suasion. The occasional requirement of regulations under public lands statutes has produced only an uninformative rehash of the statutes. Nor could it be expected

124. PLLRC Report, supra note 5, at 254 ; C. McFarland, supra note 11, at 302-04. note 97.

125. See, e.g., Robinson, supra note 4; Robinson, supra note 98; Freedman, supra

126. See notes 5-9 and accompanying text supra.

127. The Commission's recommendation was embodied in a House bill, which was never enacted. H.R. 7211, 92d Cong., 1st Sess. $\S 6(\mathrm{~g})$ (1971); see note 7 supra.

128. See, e.g., PLLRC REPORT, supra note 5, at 251-52; cf. Professor Freedman's "judicial" model of an appellate board, in which the board would be required to certify to the agency head any questions of first impression. Freedman, supra note 97, at 559. Similarly, under the Commission's proposed statute, the Board of Land Appeals would apparently be incapacitated to decide any issue other than the need for regulatory guidance, where it could not find an answer in existing law.

129. American Bar Ass'n, Resolution of the House of Delegates, adopted July, 1971 , reprinted in Hearings, supra note 72 , at 380.

130. 28 Am. State Papers (Public lands, I) 8-9 (1832), quoted in C. McFarland, supra note 11 , at 132 . 
that these unhelpful rules would be held insufficient, for the wholesale dispositions that might flow from an administrative or judicial decision that the Department had failed to adopt the rules necessary to limit private claims would be simply unacceptable. ${ }^{131}$

If one cannot effectively command the Department to make all policy in advance of its application, through rulemaking, would it be possible to force rulemaking by requiring the obverse-that no policy may be made by the process of adjudication? Of course, any given decision may involve unforeseen circumstances and hence new law. But to recognize that fact of life does not imply that the decision in one case must be made conclusive or even especially forceful should the question arise again. Adjudicators, and those who argue to them, could be forbidden from regarding prior decisions in similar cases as "precedents" governing the particular case before them. In a caricature of the continental lawyer's approach to a civil code, a statute or rule could state that only statutes and regulations would be recognized as "authority."

In the abstract, one might believe such a system good discipline for the agency concerned and productive of the simplified body of law that seems essential in a field characterized by small claims prosecuted by men of limited resources. But the reality of such a system would offend traditions and habits of legal practice. Any lacuna would become an occasion for unchanneled discretion; forbidden to seek consistency in its adjudications regarding any matter left unresolved by its rules, an agency could hardly be required to explain departures from prior results. This uncertainty might fuel the rulemaking process, but it would also prove intolerable in any matter requiring investment or other reliance on an existing legal state of affairs. Inevitably, courts would become more deeply embroiled in telling agencies what their statutes and rules mean-since courts would not be forbidden the precedential process-than they need be with a doctrine that permits them some confidence in, and enables them to enforce, the consistency of agency interpretations. ${ }^{132}$ All else aside, the intended discipline could not be expected to work. Adjudicators could not easily be kept from remembering what they had written yesterday and believing that today's labors would be shortened were they able to crib some of that reasoning. Nor could lawyers be kept from more or less subtle reminders. Case names might disappear from adjudicatory opinions, but form paragraphs would likely continue in their place.

\section{B. Reform of Internal Rulemaking Procedures}

The Department, then, cannot be required to decide on the basis only of rules adopted in advance of dispute; nor, realistically, can it be required to abjure administrative precedent in cases where rules are lacking or unclear.

131. See C. McFarland, supra note 11 , at 308 ; Bloomenthal, supra note 21 , at 248 .

132. Cf. Robinson, supra note 98 , at 970 . 
Perhaps the present bifurcation of authority represented by the Office of Hearings and Appeals will encourage greater use of legislative forms of policymaking, although no evidence of such an effect has yet appeared. The Bureau, in particular, will be properly concerned to reassert its policy control, and rulemaking is now the only means available to it. Might further steps be taken?

The most important reform of the Department's internal rulemaking procedures would be to eliminate the bureaucratic obstacles that presently hamper quasi-legislative action. Checks against hasty or unwise measures are obviously required; but the Department's and the Bureau's rulemaking procedures travel far past the point where checks become obstacles. Participation in rulemaking nust become more like participation in case adjudication-a process in which an individual can play an important and formative role. Speaking to this point, Professor McFarland ${ }^{133}$ uses as a model the practice of the Treasury Department; he suggests that the Department or the Bureau, or both, establish a special office particularly concerned with stating policy in regulation form, rather than permit each part of the bureaucracy to deal with rulemaking as one of its several responsibilities. ${ }^{134}$

Creation of a new office not only would require more of a commitment from Congress (in the form of appropriations) than the piety of an edict to act only by rule, it could be effective only if it resulted in an overall reduction of the number of persons concerned with rule formulation, so that drafts do not drift back and forth along a chain of command. A single authority, to which field staff might address suggestions and realistically expect prompt action to be taken on them, might bring them closer to the rulemaking process. Drafting preliminary to proposed rulemaking should imitate rulemaking procedures, albeit within the Department: circulation of a proposal to all levels at once, with an opportunity for comment and, in appropriate cases, consultation, rather than serial drafting and revision across a series of desks. Nor does it seem essential that all policy disputes be resolved, all bases touched, before publication of the proposed rule in the Federal Register. Existing practice not only contributes to the congestion in rulemaking, but also makes the public aspects of the procedure considerably less important; in particular, outsiders who are privately consulted in advance may achieve disproportionate influence. ${ }^{135}$ The Department should view proposed rules more as exposure of a prototype than as a final test run of a fully designed and evaluated vehicle, leaving the formative consultation and negotiation to the notice-and-comment period.

A related measure would be to recognize in the Office of Hearings and

133. C. McFarLaND, supra note 11 , at 309-10.

134. This recommendation was emphatically repeated by the Public Land Law Review Commission, PLLRC REPORT, supra note 5, at 251-52, but was not carried forward into H.R. 7211, supra note 127.

135. See note 72 and accompanying text supra. 
Appeals formal authority to initiate a rulemaking process whenever it concludes that existing legislative guides-as distinct from its own decisions-accomplish less than is reasonably possible in setting out departmental policy. Any unified agency can so act when it confronts in litigation an unresolved issue which would be more profitably handled by rule. ${ }^{136}$ The Office presently calls such situations to the Secretary's attention informally; formal authority to call upon him to issue proposed rules where a need could be shown might emphasize a departmental commitment to a greater use of its rulemaking authority. ${ }^{137}$ Professor Freedman incorporates a variation of this suggestion in his "administrative" model of an intermediate appeals board, which may draft proposed rules for publication in the Federal Register on matters appearing to require such definition. ${ }^{138}$ Any measure conferring authority to draft proposed rules on the Office of Hearings and Appeals, however, would reunify the policymaking apparatus at the risk of further isolation of the operating divisions of the Department. More fundamentally, creating such authority would not in itself give the Office major incentive to use it in favor of the more familiar and less time-consuming and cumbersome techniques of adjudication; it has not been for want of critical voices that the latter has been preferred.

Incentives to action come from outside the Department-now, in the form of the case that must be decided - and the problem is to identify a similar drive for rulemaking. Might it be generated by permitting the insufficiency of existing rules to become an issue in pending litigation, or, indeed, by expanding the current bare privilege of petitioning for rulemaking ${ }^{139}$ into a procedure, as if for administrative declaratory judgment, for determining whether and how existing rules might be made more precise? On the one hand, the Secretary cannot be required to dispense the enormously valuable public assets entrusted to him, as the bill discussed above would have done, ${ }^{140}$ merely because his rules regarding the conditions on which those assets might be obtained are not sufficiently articulate; on the other, a broad and apparently well-founded consensus exists that those rules are both obscure and evanescent, to a degree that makes legal counseling needlessly complex and impairs legitimate planning. ${ }^{141}$ A procedure by which interested parties could force an effort at definition, however imperfect or infrequently used, might provide the now-absent pressure, but the need for clarification or redefinition of statutory

136. Cf. NLRB v. Wyman-Gordon Co., 394 U.S. 759, 763-64 (1969) (opinion of Fortas, J.).

137. Cf. K. Davis, supra note $\cdot 37, \S 6.13$. Part of any request for policy clarification should be a demonstration that more precise guidelines are possible. Irreducible mysteries, such as "negligence," presumably could remain in the rules.

138. Freedman, supra note 97, at 559; see text accompanying note 97 supra.

139. 43 C.F.R. \& 14.1 (1973).

140. See note 127 supra.

141. Commissioner Loevinger, however, argues forcefully that the imprecision of existing rules is the source of an administrator's power and, consequently, is seen by him as an asset to be defended rather than an imperfection he can be enlisted to help curb. Loevinger, supra note 58, at 380. A dour view, but not an unpersuasive one. 
terms and existing rules should not provide an occasion for permitting private claimants to prevail where their claims otherwise would have failed.

Alternatively, the Board of Land Appeals might develop and use some of the techniques courts sometimes employ to provoke legislative clarification: "If $\mathrm{X}$ is what is meant, against the important interests of a private person, it must be more clearly stated in the governing law." ${ }^{42}$ But larger reasons often lurk behind the judicial uses of this device, which has not always catalyzed legislative action or been intended to do so. The bromide that a document is to be construed against its drafter, when applied to statute or rule rather than a contract drawn by the parties to the dispute for application to the particular occasion, has but limited validity. Save in special circumstances such as criminal law, where notice and clarity are considered particularly important, legislative documents are ordinarily construed with an eye to good sense and "intended" meaning, not against the party responsible for drafting them. Only a dramatic failure to forge rules out of demonstrably malleable material, if any failure at all, could warrant compelling recognition of private right in government property on that account alone.

\section{Controls over Decisions of the Board of Land Appeals}

A final series of measures possible to minimize the division in policy function involve provision for secretarial control over the policymaking dimension of adjudication. A small but important first step, to avoid any possible confusion among lawyers or conflicts within the Department, would be to have the regulations establishing the Office of Hearings and Appeals include a statement of the laws by which it is governed, and a clarification of the precedential force of Board decisions. One of the occasional characteristics of common law litigation about statutes is that exegesis of prior judicial reasoning overtakes the text; some have thought the Department particularly prone to this development. ${ }^{143}$ Impractical as it may be to seek to strip the Board's decisions of all precedential force, some function might be served by a provision, in the manner of occasional codifications, that its prior constructions of the Department's statutes and rules are authoritative only to the extent they remain consistent with current departmental policies and approaches. The changes which have occurred in the Department's reading of its governing statutes—say, the discovery standard - are and should be seen as the product of changing policy, not the deposit of quasi-judicial decisions as such.

Larger, institutional steps are also possible. One would be adoption for use by the Board of a hybrid procedure requiring it to certify important policy issues for secretarial decision after public notice and an opportunity for com-

142. See Kent v. Dulles, 357 U.S. 116, 129 (1958).

143. Compare C. McFarland, supra note 11, at 308, with Kosanke Sand Corp., 12 I.B.L.A. 282, 3 ENVIRON. L. ReP. 30017 (1973). 
ment, reserving for the Board's own decision the question of applying the policy then adopted to the particular case. Alternatively, provision could be made for discretionary secretarial review, the reactive approach which seems to have been anticipated by the Conference and the ABA in their recommendations for creation of intermediate appellate bodies. ${ }^{144}$ Or, the Secretary, through the issuance of Solicitor's Opinions, involving neither the formulation of policy nor reversal of its application in the particular case, could voice disapproval of particular Board decisions, leaving the policy question unsettled for future cases. Finally, the Board's holdings could be given maximum effect while retaining secretarial control over policy formulation if the Secretary were authorized to seek, and be bound by, judicial review of adverse holdings -as, for example, the Commissioner of Internal Revenue may seek review of Tax Court decisions. ${ }^{145}$

A provision for discretionary secretarial review would be the most orthodox response. Models can be found in the various executive departments as well as in the multi-member independent agencies that were the apparent focus of the Bar Association and Administrative Conference recommendations. ${ }^{146}$ But a three-level tier of administrative decision involves elements of possible unfairness to private litigants, particularly if, as in the Department's public land matters, their capacity to support the expense of litigation is often marginal. The Department's elimination of the appeal to the Director of the Bureau, previously an intermediate step to final departmental decision, was itself made in recognition of possible unfairness worked by the costs of a multistage procedure. Where the issue is merely unifying the policymaking function, the justification for imposing the risks and expense of additional proceedings entirely on particular litigants is open to doubt. ${ }^{147}$

The Solicitor's Opinion offers a vehicle less costly to individual litigants for blunting the force of unacceptable appellate board decisions. Just as the Internal Revenue Service announces its acquiescence or occasional nonacquiescence in decisions of the Tax Court, the Solicitor's Office might be authorized by the Secretary to announce reasoned disagreement with decisions of the Board of Land Appeals. That opinion, obviously, would not affect the outcome of the particular case. But it could be given the effect of removing precedential force from the decision disapproved, subjecting the issue involved to redetermination either in ensuing litigation or by rule. The rejection of the Board of Land Appeals' prior decision, together with the reasons stated for rejecting it, might have forceful effect should the Board again be called upon to resolve

144. See note 96 supra.

145. Cf. 26 U.S.C. \& 7483 (1964) (Tax Court) ; S \& E Contractors, Inc. v. United States, 406 U.S. 1, 60-68 (1973) (Brennan, J., dissenting).

146. See, e.g., 8 C.F.R. \& 3.1(h) (1973) (Attorney General may review decisions of the Board of Immigration Appeals sua sponte or at the behest of the Board or the Commission of the Immigration and Naturalization Service).

147. Cf. Kosanke Sand Corp., 12 I.B.L.A. 282, 3 Environ. L. Rep. 30017 (1973). 
the issue ; as a published document, the Solicitor's Opinion would be available to both sides for citation in the case and doubtless would be cited. The appellate board, however, would again remain formally free to make its own reading of the issue presented.

The judicial model, indeed, has its flaws when adapted to the administrative context. But if the Department feels compelled to grant court-like independence to the Board of Land Appeals, giving up centralized policy control, it might also assert that the judicial model of appeal by either side should apply. It is hard to escape the thought that the Department's Solicitor might wish equal redress for his "grievances" as any private party. ${ }^{148}$ And in some cases, notably those involving Forest Service lands, neither litigator before the Board has any formal connection with the Department of the Interior. The Forest Service, in pursuit of its own statutory and regulatory mandates to manage its lands efficiently, may come to believe that the Board (or, through it, the Department of the Interior) has failed to recognize some special factor, misread the governing statutes, or encumbered Forest Service lands without substantial evidence in support; judicial review at its behest would be one means, and perhaps the fairest to all parties concerned, for resolving the dispute.

This last possibility is perhaps unlikely. ${ }^{149}$ It would require statutory

148. It is not inconceivable that private clainants would be benefited thereby. Their prevailing complaint is that the Department remains too conservative regarding recognition of claims-that the ghost of Albert Fall still stalks the corridors, rendering departmental bureaucrats unwilling to recognize private claims of right. The unreviewability of decisions to recognize claims must (and on the evidence of informal discussions does) influence decision; an erroneous denial can always be reviewed, but not an erroneous grant, and hence it is safer to deny in cases of doubt. The Board of Land Appeals might be led to greater evenhandedness in managing its doubts if assured that both parties appearing before it had an opportunity to correct its errors.

Yet more speculative is the possibility that reviewing courts, faced with contentions that the Board had been too solicitous of private claims or not solicitous enough, would acquire a more balanced view of the Board's decisional processes. When court decisions speak of the limited nature of judicial review, they perhaps already recognize and adjust for the negative posture of suits seeking to overturn agency denials of private claims. As cases asserting insufficient agency aggressiveness have slowly begun to appear, the courts entertaining them have voiced perceptions of a "new era" in judicial-administrative relations. See, e.g., Environmental Defense Fund, Inc. v. Ruckleshaus, 439 F.2d 584, 597 (D.C. Cir. 1971). What seems to be involved is the recognition that the consistently negative character of traditional provisions for review, responding only to private assertions that the agency had gone "too far" in encroaching on private rights, tended to foster timidity in regulation by the agency; it had to fear judicial assault only on one front, and the courts, too, because accustomed only to that limited perspective, rarely encountered allegations of administrative lassitude or over-permissiveness. So far as the Department is concerned, however, there is no indication that in recent years judicial control has been a significant factor; final reversals of its actions have been quite rare.

149. But see Department of Agriculture Letter, supra note 123, at 2. This approach, while unlikely to be adopted, should be able to overcome any constitutional difficulties. The obvious difficulties regarding the existence of a constitutional case or controversy, less severe for the Forest Service, could be avoided if the Board were given independent status by statute, cf. 26 U.S.C. $\$ \$ 7441,7483$ (1964) (U.S. Tax Court), or if the Department would merely repudiate the unacceptable internal holding and await private suit.

Nor should considerations of fairness to private litigants bar this approach. True, the Supreme Court in S \& E Contractors, Inc. v. United States, 406 U.S. 1 (1973), rejected non-statutory arguments for Government-initiated review of the findings of an 
authorization, and the more broadly sweeping substantive reforms now proposed would moot the problem. Agencies are not courts, and for a variety of reasons should be left to resolve such disputes through the internal mechanisms of the Executive Branch-within the Department, through the Secretary; between the Department and outsiders such as the Forest Service, through the Office of Management and Budget, informal negotiation, or the President himself. Lapses by the Board may offer encouragement to rulemaking, and the Government's interest in the particular land affected by arguable error is not usually so great as to render the other possibilities suggested inadequate, nor is the incidence of internal or interdepartmental disputes regarding the correctness of the Board's decisions now substantial. Yet the absence of a judicial remedy when disputed issues of law are resolved against the position of the Government's attorneys appearing before the Board should stand as a caution against excessive insulation of the Board from the rest of the Department's policy-setting apparatus.

The better course might be steps in the direction of hybrid procedures, introducing elements of rulemaking into those cases in which large issues of interpretation, unresolved or imperfectly dealt with in the Department's rules, appear. Hybrid procedures seem to be most frequently viewed as a mode for increasing the discipline of rulemaking proceedings, but as some have suggested, ${ }^{150}$ they are equally apt for expanding the scope of adjudication when an issue of general importance is found to be involved in pending litigation. Published notice of the problem posed and a proposed ruling with opportunity for public comment would avoid the problems of inadequate public participation and representation which critics have noted in the past, ${ }^{151}$ and possibly ease the financial burden for the individual respondent. Incorporation of the result of this notice-and-comment proceeding in the Department's rules as well as its reported decisions would tend to simplify the presently over-complex task of finding its governing law. The Department, not formally subject to the Administrative Procedure Act's rulemaking or adjudicatory procedures, ${ }^{152}$

analogous independent adjudicatory body within the Atomic Energy Commission. There the majority, over a strong dissent, protested sharply what it deemed the unfairness of requiring a litigant, successful before the AEC, to run the further "gantlet" of "review" by other agencies (the General Accounting Office and the Justice Department) as a prelude to those agencies precipitating judicial review on behalf of the United States. $I d$. at 14-15. The majority found both the administrative "review" by the other agencies and judicial review at the request of the United States to be unauthorized by statute. Had the statute been explicit, however, nothing suggests the Court would have found a constitutional barrier to the procedure. And the assessment that forcing the litigant to run the further gantlet is "unfair" blinks the deliberate effort to make the board whose decision is thus appealed "independent" of agency influence, itself in the interests of fairness. One cannot have it both ways.

150. E.g., Clagett, Informal Action-Adjudication-Rulcmaking: Some Recent Developments in Federal Administrative Law, 1971 Duke L.J. 51, 83. Cf. 2 Administrative Conference of the United States, Recommendations and Reports, ACUS Rec. 71-3, at $24,175-80$ (1973).

151. See text accompanying notes 64-78 supra.

152. The statute does not formally require a hearing. Those aspects of the Act's 
is in a particularly favorable position to undertake procedural experimentation of this sort.

Such procedures would be more appropriate at the Board level than before the Department's administrative law judges. Awaiting appeal permits a more accurate assessment of the importance of the issues, and the record compiled at the initial hearing should both illustrate the ambiguity or insufficiency of existing policy guides and afford a basis for resolution of the immediate controversy. The suggestion is that the Board be empowered, either on motion of a party or sua sponte, to publish in the Federal Register notice of policy issues thus framed and of their suggested resolution. The suggested resolution might be the Board's, but use of the Departmental Solicitor's position would reflect the Secretary's proper hegemony over policy issues. Notice-andcomment rulemaking would ensue. Once all comments had been received, final decision of the policy issue (but not its application to the particular case) should be possible, at least formally, at the secretarial level; in any event, the less confining strictures of rulemaking processes would apply. Application of the policy in the particular case, however, or decision of the case without secretarial input, should legislative statement prove infeasible or unnecessary, would be left to the Board's present adjudicatory processes.

Adoption of such a procedure undoubtedly would stir arguments regarding the "prospective" application of rules and permissible "retroactivity" of adjudication. The claim would be that, having infected the adjudicatory process with general public participation and open consideration of concededly unresolved policy issues, the Department could no longer fairly apply the result of its proceedings to the case at hand. As Professor Robinson has convincingly shown, however, the prospectivity-retroactivity distinction, like other formal differences between rulemaking and adjudication, has been considerably overdrawn. ${ }^{153}$ If properly subject to the possibility that his rights would be determined by adjudication, a claimant suffers no discernible injury from the choice of a slightly different, fair and yet more catholic procedure to investigate the policy questions involved. At most, he is entitled to an opportunity-such as he would have in the strictly adjudicatory context as well-to show equitable bases for a claim not to have the new standards applied to his detriment: for example, that prior law, upon which he properly relied, was clearly in his favor ; that past events, in particular, should not be judged by a standard clearly different from that which seemed to govern at the time; or the like. ${ }^{154}$ Where

adjudicatory procedures which can be linked to considerations of constitutional due process have been acknowledged to apply to the Department. See Adams v. Witmer, 271 F.2d 29, 32-33 (9th Cir. 1958). But if procedures adequate to meet the demands of fairness are assumed, the Department is relatively free of formal constraints.

153. Robinson, supra note 4, at 517-19; see also Shapiro, supra note 4, at 933, 952-57.

154. See Lemon v. Kurtzman, 411 U.S. 192 (1973) (denial of retroactive effect to new constitutional understanding). Cf. Robinson, supra note 4, at 525-26; Shapiro, supra note 4, at 952; Massey Motors v. United States, 364 U.S. 92, 108 (1960) (Harlan, J., dissenting) ; K. Davis, supra note $37, \S 5.09$. The common perception that the Department 
prior law has been uncertain, or the question is what future showing must be made or conduct performed with respect to existing claims, such equitable bases could not be established, and full application of the determination made in the hybrid proceedings to all claims would be entirely justified. The common practice under regulatory statutes such as the Mineral Leasing Act is to include in the lease agreement an undertaking to be bound by future changes in governing regulations; so here. In the context of a claim to government property gratuitously made available to private interests, not private property subjected to outside control, the citizen's claim to "non-retroactivity" is fairly limited to the avoidance of adverse consequences from behavior apparently lawful when undertaken -without regard to the character of the proceedings in which the rules governing his obligation are eventually defined. While existing claims obviously could not be abrogated by fiat, neither Congress nor the Department lacks authority to clarify governing law or to alter for the future the circumstances under which the claims are held.

\section{ConcLusion}

The search for mandatory controls over the allocation of the policymaking function between rulemaking and adjudication remains illusory. The legislative recommendations of the Public Land Law Review Commission were wisely left to wither by Congress, and the Supreme Court, with equal wisdom one might believe, refused to endorse judicial controls. The case could be made that the issue of allocation is a "straw man"- that the only outcome-determining issue will be the fairness of retroactive application of new "law" in the adjudicatory context. The Supreme Court's decision in NLRB v. Wyman-Gordon Co. ${ }^{155}$ teaches us that the retroactivity problem does not exclude the creative use of ostensibly adjudicative technique. ${ }^{156}$ Yet whether or not controls are applied, there remains a body of belief that for some purposes rules are the superior

has failed to recognize just reliance claims is one of the most fertile sources of discontent within the private bar regarding its administration of the mining law. The Department must remain free to change its interpretation of governing law when a previous position appears to have been in error, with adverse consequences for the future expectations even of those who acquired benefits under the prior rule. Absent such authority, venal or shallow administrators could too easily commit valuable resources to perpetual waste. No contemporary corrective is available to the Government. But it does not follow that the interpretation in question may be given no force for the period during which it persisted. Reliance, appropriate in the existing circumstances, may indeed have been placed on the existing state of the law. Absent an error so clear that it itself serves notice of its absurdity, or some other notice that the interpretation is under question, there is little justice in a rule permitting the Government to ground adverse consequences in another's reliance on existing interpretation. Massey Motors v. United States, supra, at 108. Nothing in the decided cases endorses, much less requires, that result; while the private citizen may acquire no rights by reliance on erroneous Government interpretation, neither should he be found to have lost any through that reliance. $C f$. United States v. Winegar, 16 I.B.L.A. 112, 4 ENvIRON. L. REP. 30005 (1974).

155. 394 U.S. 759 (1969).

156. Id. at 755-56 (opinion of Fortas, J.), 771 (opinion of Black, J.). See also NLRB v. Bell Aerospace Co., Division of Textron, Inc., 94 S. Ct. 1757 (1974) ; NLRB v. Majestic Weaving Co., 355 F.2d 854, 860-61 (2d Cir. 1966). 
vehicle. Where clear, accessible rules are possible, it disserves the public to compel it to disentangle a web of sometimes obscure and hidden law sources. Only lawyers stand to gain, if anyone does, from needless complexity. Broader participation in the formulation of policy is encouraged in the rulemaking context ; it both assures direct policy control and reduces somewhat the impact of new law on settled expectations. "Since [an agency], unlike a court, does have the ability to make new law prospectively through the exercise of its rulemaking powers, it has less reason to rely upon ad hoc adjudication to formulate new standards of conduct. ...."157

In the Department of the Interior, however, and perhaps elsewhere, the concept of "allocation" suggests processes which do not occur. Coordination, unified control over the choice of policymaking technique, much less its outcome, is simply lacking. The principal determinants in the largely unconscious mechanisms by which issues find their way into one or another process are inertia and rulemaking procedures so choked as to be virtually impassable. Refurbishing those procedures and establishing techniques for unification of policy seem more important than artificial techniques for directing policy issues into one or the other channel.

157. SEC v. Chenery Corp., 332 U.S. 194, 202 (1947). 